\title{
Tim Hope
}

\section{Community Crime Prevention}

\begin{abstract}
A B S T RA C T
Community crime prevention refers to actions intended to change the social conditions that are believed to sustain crime in residential communities. Different approaches have evolved, which can be best understood as a succession of policy paradigms emerging as responses to changing urban conditions: community organizing; tenant involvement; resource mobilization; community defense (both intentional organizing and environmental modification); preserving order; and protecting the vulnerable. Prevention in high-crime areas presents particular difficulties for community approaches. Community approaches have foundered mostly because of insufficient understanding of the nature of social relations within residential areas and of how community crime careers are shaped by the wider urban market.
\end{abstract}

Community crime prevention refers to actions intended to change the social conditions that are believed to sustain crime in residential communities. It concentrates usually on the ability of local social institutions to reduce crime in residential neighborhoods. Social institutions encompass a diverse range of groupings and organizations-including families, friendship networks, clubs, associations, and organizationswhich bring people together within communities and, by doing so, transmit guidance concerning conduct in the locality. Together, such institutions make up the social structure of residential communities. In this essay, the distinctiveness of community crime prevention is

Tim Hope is reader in criminology, Keele University, and coordinator of the Economic and Social Research Council Crime and Social Order Research Program. The author is grateful for comments from Tony Bottoms, Dennis Rosenbaum, Michael Tonry, and the participants at the editorial conference in London.

(4) 1995 by The University of Chicago. All rights reserved.

0192-3234/95/0019-0003\$01.00 
seen to lie in its purposive concern to alter the social structure of particular communities. Not included therefore in this definition are macro-level economic and social policy measures which have chiefly an indirect effect on local social structure-though, as will be seen, these may have an important influence on the ability of community institutions to affect crime-and programs delivering social or correctional services to individuals, albeit located in community settings.

How should we think about community crime prevention efforts? It is often an implicit belief of social scientists that the findings and theories of social research can be translated directly into social programs or that such programs can be construed as the precise embodiment of particular social theories (Rein 1976; Lindblom and Cohen 1979). Yet, in reality, practitioner accounts of community crime prevention often seem muddled, inconsistent, and untheorized (see Rock 1988). In these circumstances, it is tempting to want to convert practical discourse into a rational theory. Yet this may hinder rather than help us understand the political character of community crime prevention. In the approach adopted in this essay, various forms of community crime prevention are interpreted not only as applications of criminological theory but also as complex pieces of sociopolitical action that also have a defining ideological and ethical character.

A conceptual tool that can help in delineating the emergence of different types of community crime prevention over the years is the policy paradigm, "a curious admixture of psychological assumptions, scientific concepts, value commitments, social aspirations, personal beliefs and administrative constraint . . . a guiding metaphor of how the world works which implies a general direction for intervention" (Rein 1976, p. 103). A principal question that this essay addresses is why community crime prevention paradigms change. The explanation is that paradigm replacement has not been simply the result of an accumulation of program failures and successive bright ideas-that is, a "what works"-type progression-but rather that eventually it becomes apparent that the prevailing rationale underpinning a particular paradigm has failed to comprehend the changing nature of the crime problem in the urban environment. During the twentieth century, metropolitan areas have changed dramatically, as has the perception of crime problems within them. Shifts of community crime prevention paradigm reflect those changes.

An overview is offered here of crime prevention ideas and programs 
as they have been proposed for residential areas. Rather than unnecessarily - and probably less successfully-duplicating the detailed findings of a number of relatively recent and comprehensive reviews of research (Titus 1984; Lavrakas 1985; Rosenbaum 1986, 1988a; Taylor and Gottfredson 1986; Skogan 1988, 1990), an attempt is made here to explore the way in which the idea of community prevention has been interpreted, what problems the emergent programs of the time were trying to counter, and whether they constituted an effective or appropriate policy response to the crime and community problems that had occasioned them.

The essay revolves around a central paradox: there has been a continuous and consistent pattern of criminological research suggesting that community structure itself shapes local rates of crime-that community crime rates may be the result of something more than the mere aggregation of individual propensities for criminality or victimization (Sampson 1987a; Bursik and Grasmick 1993). Yet much of the effort to alter the structure of communities in order to reduce crime has not been noticeably successful or sustainable. Does this mean that the community approach, as a strategy of prevention, should be abandoned, despite the weight of research pointing to the importance of community life in crime causation?

Initially, it would seem that it might be possible to resolve the paradox if we could work out whether the problems of community crime prevention were due to a failure of theory - that the program rationale was wrong-or of implementation-that the aims were right but the means to achieve them were inappropriate, inadequately implemented, or underresourced (Rosenbaum 1986). Yet, in fact, it is hard to find an example among most of the programs reviewed here where implementation was so successful that a proper evaluation of theory could be made. Indeed, it would appear impossible clearly to separate means from ends in community crime prevention. This may be because, in most formulations of the community approach, the proposed solution-a community structure that controls crime-is also the antithesis of the perceived problem-a community that does not control its own crime. With such circularity, means and ends become blurred; and a failure of implementation is as much a failure of theory as of practice.

A more helpful distinction may be between two dimensions along which local social institutions-and purposive prevention programsoperate in communities (Duffee 1980; Sampson 1987a). First, there is 
a "horizontal" dimension of social relations among individuals and groups sharing a common residential space. This dimension refers to the often complex expressions of affection, loyalty, reciprocity, or dominance among residents, whether expressed through informal relationships or organized activities. Second, there is a "vertical" dimension of relations that connect local institutions to sources of power and resources in the wider civil society of which the locality is acknowledged to be a part. This essay suggests that the two dimensions are equally important-and related-in their effect on local crime (Bursik and Grasmick 1993) and therefore crucial for crime prevention efforts in communities.

While the principal mechanisms for maintaining local order may be expressed primarily through the horizontal dimension; the strength of this expression-and hence its effectiveness in controlling crimederives, in large part, from the vertical connections that residents of localities have to extracommunal resources. Many of the approaches reviewed here have either neglected to address sufficiently the vertical dimension of community power (or powerlessness) or have met with failure or resistance when they have done so. The paradox of community crime prevention thus stems from the problem of trying to build community institutions that control crime in the face of their powerlessness to withstand the pressures toward crime in the community, whose source, or the forces that sustain them, derive from the wider social structure.

Most of the material here comes from accounts of programs and research carried out in the United States and Great Britain, describing policy paradigms of community crime prevention in terms of responses to changes in urban conditions and governance, though these may also be similar to developments in other advanced societies (see Jacobs 1992).

The discussion of each paradigm is organized under the following headings: problem definition-which includes implicit concepts about community, .crime problems, and urban dynamics; strategy-by which is meant the rationale or theory justifying the focus of prevention (i.e., whether to block criminal behavior, forestall criminal motivation, or promote social control) and the way in which program inputs were intended to result in crime prevention outputs; implementationwhich includes the policy processes leading to specific programs and the course they took in practice; and evaluation, including both the available research evidence on effectiveness and the broader political 
assessment that occasioned the paradigm's demise or the persistence of some of its elements.

The essay is divided broadly into four sections. Section I discusses the paradigms of community prevention that emerged under conditions of urban growth during this century. These include "community organizing," "tenant involvement," and "resource mobilization." Section II considers the paradigmatic response-"community defense" to the urban problems of the 1970s and 1980s, consisting of two forms, "intentional organizing" and "environmental modification." Section III seeks to discern approaches emerging during the 1980s, particularly, the preservation of community order and the reduction of victimization. Section IV, by way of conclusion, reflects on what has been learned so far and points to the likeliest or most-promising next steps in research, program development, and policy formulation.

\section{Community Crime Prevention in the Growth City}

Three community crime prevention paradigms arose in response to the problems of order posed by the demographic and economic expansion of cities. The first is community organizing, associated primarily with the diagnosis of the urban condition put forward by the Chicago School of Sociology, and with the programs of Clifford Shaw and Henry McKay. The second-tenant involvement-owes much to the first, though it arose in response to problems associated with the growth of public housing, especially in mid-century Britain; the third-resource mobilization-is a model that came to be embodied in the troubled history of the "War on Poverty" program in the United States during the 1960s (Marris and Rein 1972; Lemann 1991) and, less directly, in the travails of the Community Development Project in late-sixties Britain.

\section{A. Community Organizing}

The Chicago School's enduring legacy for community crime prevention, and for urban reform generally, is the rationale of "community action"-or in Britain "community development": "A way must be found to modify those aspects of community life that provide the appropriate setting for delinquency careers and which give those careers the sanction and approbation on which all social behavior depends" (Shaw and McKay 1969, pp. 325-26). The general model saw the city's social and physical form as determined by relatively unregulated competition for urban space between industrial or commercial and 
residential uses and between social groups differentiated by income and ethnic and cultural identity (Park, Burgess, and McKenzie 1925; Bursik 1989). The land and property pricing of the city reflected the outcome of unfettered competition for access to urban resources. As immigrant groups and individuals arrived, adjusted, and made economic progress, so they would move successively to the areas of the city that were appropriate for their particular stage of social mobility, succeeding other groups further along the process of assimilation to the urban way of life. Shaw and McKay's extensive areal correlation analyses tended to corroborate this ecological depiction (Shaw and McKay 1969): despite changing ethnic populations, inner zones of American cities had high rates of resident juvenile offenders and-by virtue of their position in the ecological structure of competition for urban space-were of mixed land uses, low socioeconomic status, cultural heterogeneity, and high transience (Kornhauser 1978). Because these areas contained social groups undergoing a process of transition to urban ways, they would be disorganized, creating a moral vacuum in which youth, without guidance or control, would be free and susceptible to criminal activity.

1. Strategy. Shaw and McKay failed to describe the particular features of social disorganization or, from the point of view of criminological theory, to provide a consistent account of how social disorganization caused individual delinquency (Wootton 1959; Kornhauser 1978). However, it is arguable whether Shaw and McKay actually needed an individual-level theory to guide preventive action. Since the areal analysis seemed to confirm that the prevalence of delinquency was consistent with the Chicago School's structural model of the distribution of resources and pathology between neighborhoods of the city, despite changes in their populations, then it followed, logically, that delinquency would be a property of areas, which is the level at which Shaw and McKay thought that intervention should be targeted (Shaw and McKay 1969, p. 321). Their position seems to have been, not that individualized methods of curbing delinquency-by inculcating moral values or providing standards of guidance-would be ineffective, but that the institutional infrastructure for implementing these methods was lacking: "Through the leadership of local residents it is possible to effect closer co-ordination of local institutions, groups, and agencies into a unified program for the area as a whole" (Shaw and McKay 1969, p. 322, emphasis added). 
2. Implementation. In order to compensate poor communities for their lack of institutional infrastructure, and mindful of the "humiliations often entailed in receiving the services of philanthropy" (Shaw and McKay 1969, p. 323), Shaw initiated the Chicago Area Project (CAP) in 1932, which, in one way or another, has been the source model for community action to the present (Bursik and Grasmick 1993). Chicago Area Project programs were initiated in about six small areas of Chicago. Reportedly, they all pursued, with varying degrees, recreational programs for children, campaigns to improve conditions in the neighborhood, and outreach work ("curbstone counseling") with delinquents and gang members (Kobrin 1962). Many of the techniques pioneered by CAP have become subsequently the staple methods of the community treatment of delinquency and of community development. Yet, in an important way, the substantive content of the programs was held to matter less than the opportunities for socializing young people that the participation of community adults, as role models, provided (Kobrin 1962).

While there have been general descriptions of the Chicago Area Project (Kobrin 1962; Finestone 1976), Schlossman, Zellman, and Shavelson (1984) provide the only detailed, long-term account of its progress. They focus on the Russell Square area of South Chicago and divide events into two periods: $1931-44$, and 1944-84. They characterize the first period as one of mutual adaptation-between CAP's ideals and what the indigenous community were actually prepared to do: "CAP entered Russell Square slowly and cautiously, and by the timeworn path of least resistance to children and parents alike: organized recreation. . . . Shaw expanded recreational contacts with juvenile gangs to include extensive curbstone counselling. Becoming fully rooted and accepted in the neighborhood, though, required more than CAP energies alone could provide. . . . Shaw carefully courted the local catholic church and influential catholic laymen . . . to local residents, the CAP may have appeared mainly as an appendage to St. Michaels. To the pragmatist in Shaw, the church connection was essential to get his own experiment off the ground" (Schlossman, Zellman, and Shavelson 1984, p. 22).

A test of Shaw and McKay's theory of community organizing is whether community institutions survive despite population change. During the second phase of CAP in South Chicago (1944-84), the population changed dramatically from a Polish working-class neighbor- 
hood to a predominantly Mexican neighborhood with a minority of blacks (Schlossman, Zellman, and Shavelson 1984). With the departure of the Poles to the suburbs, the institutions around their local church disintegrated. Yet CAP quickly transferred its support and funding to two nascent community organizations emerging in the Mexican and black communities. Nevertheless, little attempt was made to organize the separate groups to serve the neighborhood as a whole: "Once again, the CAP accepted ethnic exclusivity as a precondition for getting things done" (Schlossman, Zellman, and Shavelson 1984, p. 30).

3. Evaluation. Not perhaps surprisingly, Schlossman, Zellman, and Shavelson (1984, p. 20) report that, over the years, "Shaw became more and more reluctant to cite statistical data on delinquency rates to demonstrate the wisdom and effectiveness of the Area Project." Their own attempt to assess crime levels in the community in 1980 exhibits the unreliability of ex post facto, cross-sectional analysis (Lurigio and Rosenbaum 1986). Yet, the history of CAP is important, not because it demonstrates crime reduction, but because it illustrates what will turn out to be three of the common problems facing the implementation of community crime prevention (see Skogan 1988).

First, there was the need to select communities where there was already some community infrastructure. As Finestone (1976) suggests, CAP was not actually implemented-nor did it long survive-in the most disorganized neighborhoods of the day but rather took root in somewhat more stable, ethnically homogeneous neighborhoods. Although, pragmatically, some preexisting institutional infrastructure may have been necessary for survival, such selectivity tends to undermine the primary objective of building community institutions where they are lacking. Second, there is the difficulty of sustaining indigenous community involvement over the longer term. When the institutional structure supported by CAP fell apart as a result of population change, it changed support to new embryonic structures but did not create them itself. Without the external input of CAP, it seems unlikely that the indigenous institutions would have survived the cultural and population turnover of the neighborhood.

Third, there are differences between the theoretical goals of the intervention and what the community itself defines as important and desirable as a condition of acceptance. The difficulty of engaging the voluntary commitment of adults to the theoretical aims of CAP seems to have led in practice to a degree of compromise in the goals of CAP in an effort to build the institutions of socialization. For example, "It 
became clear that Russell Square youth wanted to go to camp ... and that the community considered camping an essential tool of delinquency prevention. ... Shaw became reconciled to camping as integral to the Area Project philosophy" (Schlossman, Zellman, and Shavelson 1984, p. 22).

In sum, while CAP has shown remarkable longevity (Bursik and Grasmick 1993), that may have been due less to the scope of local institutions-that is, the horizontal dimension of community relations-so much as to the persistent sponsorship of agencies external to the community - that is, the transfer of resources down through the vertical dimension of community relations. In any event, it would seem that CAP failed its own test-of building community institutions that would regenerate themselves without external intervention and despite change in membership.

\section{B. Tenant Involvement}

The legacy of community organizing bequeathed by CAP has exerted a lasting and general influence on subsequent thinking about community work across a range of policy fields. Although not explicitly acknowledged, some of the spirit of the CAP approach reemerged during the 1970s in response to the problems presented by the expansion of public housing in Britain-specifically, the desirability of involving tenants in the management of their residential environment.

The postwar period in Britain saw a massive increase of housing in public ownership-in 1945, about 12 percent of households lived in public housing, a figure that grew to 3.1 percent by 1971 (Bottoms and Wiles 1986). This growth was largely due to the extension of public involvement in postwar reconstruction and urban renewal. Much of this growth involved the building of often large-scale public housing estates both in the inner cities and on the periphery of urban areas. Yet by the 1970s, at the end of this period of construction, problems of vandalism and deterioration began to emerge on public housing estates, some of which had only recently been built (Ward 1973; Power 1987a).

An investigation by the Department of the Environment for England and Wales focused on the development of "problem estates" (Department of the Environment 1981). It concluded that some estates had acquired an adverse reputation that, when combined with an inability to maintain them to an adequate standard, resulted in a spiral of decline that was characterized by vandalized and poorly maintained public 
spaces and little sense of community among residents. As a result, there was a high turnover of tenants, with vacancies attractive only to those in desperate need. All this led to an atmosphere of neglect making it harder for housing services to cope with increased problems of maintenance, lettings, and rent arrears. In many respects, the "problem estate" in Britain by the 1970s replicated, in the public housing sector, many of the features of high-crime communities identified in a different context by Shaw and McKay - public housing had grown, and newly created estates were bringing diverse populations together, often with concentrations both of children and poverty, while the unpopular estates were seen as an environment in which residents passed through on their way to better estates, leaving behind those families with multiple difficulties.

1. Strategy. Two related strands of an approach emerged: first, intensive decentralization of housing management and services to the level of the estate itself, which could then be focused with a greater degree of effort, coordination, and efficiency (Power 1984); and second, consultation with tenants on all aspects of estate improvements and the creation of ways in which they would be able to become involved in the direct management of estates. It was this latter aspect that had affinity with the CAP approach-to create institutional arrangements for tenants to control their living environments. Accessible provision of housing services would reinforce these arrangements. Together, they would help empower tenants-by making estates better places to live, they would persuade current tenants to stay, thereby providing stability to estate communities (Power 1984, 1987b). Nevertheless, although it has been claimed that crime has declined as a result of this strategy (Burbidge 1984), many have seen this as an indirect consequence of the strategy's chief aim to bring about general physical improvements to the housing estates (Glennerster and Turner 1993).

2. Implementation. In Britain, initiatives have sought to arrest the deterioration of problem estates by decentralization and improvements in the quality of housing management, services, and maintenance, through small-scale environmental improvements and clean-up programs and by supporting greater consultation and involvement of residents in the management of their estates (Bright and Petterson 1984; Power 1987b; Rock 1988; Foster and Hope 1993; Glennerster and Turner 1993). With respect to tenant involvement, many projects drew their inspiration from a pilot scheme in Widnes in 1975 (Hedges, 
Blaber, and Mostyn 1980) sponsored by the National Association for the Care and Resettlement of Offenders. Also influential has been a government-sponsored program of projects run by the Priority Estates Project (PEP) (Power 1984, 1987b) and, later, also supported by Estates Action of the Department of the Environment for England and Wales. Both programs have been seen as models of good practice for local housing authorities to follow (Power 1987b). Typically, such schemes involve a variety of measures-including security programs for dwellings, clean-up projects, localized management, caretaking, and concierge services-though the key ingredient has always been consultation and involvement of tenant representatives in management issues.

3. Evaluation. While a considerable number of estate-based initiatives have been implemented in Britain, documentation from evaluative research has been somewhat lacking. In part, this may have been due to the opacity of the processes of change involved, the scale and complexity of the interventions, the reluctance to use or accept empirical evidence or detailed analysis, and the obstacles and lack of resources that implementers may have experienced in presenting accounts of their work (Rock 1988). In part, also, there remains the general evaluative problem of isolating the particular effects of multidimensional projects (Foster and Hope 1993). A report by the Safe Neighbourhoods Unit (Safe Neighbourhoods Unit 1993a) brought together evidence from a number of management-led initiatives on public housing estates in Britain (see also Burbidge 1984), concluding that "on balance . . . estate-based local management initiatives appear to have an impact on crime problems where they are part of a broad programme of physical and social improvements ... results from assessments are encouraging but further evidence is required" (Safe Neighbourhoods Unit 1993a, p. 108).

Recently, Hope and Foster (1992) and Foster and Hope (1993) have evaluated the impact of a management/consultation approach, implemented by the Priority Estates Project, in two areas of public housing in England-one in inner London, the other in the Northern English city of Hull (see also Glennerster and Turner 1993). The study used a quasi-experimental research design to compare changes occurring in each of the areas over a three-year period with a matched control area. A range of data sources was used: pre- and postimplementation household surveys to assess levels of victimization, fear of crime, and tenants' experiences of estate conditions, housing services, and community life; 
detailed ethnographic observation and interviews with tenants over twelve months on one estate and eighteen months on the other; recorded crime figures; the regular measurement of environmental standards on the estates; and the monitoring of changes in the delivery of housing management and services.

At the outset of the study, the two estates selected to become new PEPs both had high crime rates and adverse design and social characteristics. The basic elements of PEP's housing service model-a local estate office, repairs, caretaking, lettings-were implemented on both estates (Glennerster and Turner 1993). However, in the first year of operation on the London experimental estate, the estate office was run by a housing manager who appeared to have little sympathy with the PEP approach, causing friction with the tenants and the PEP consultant. While some estate services improved, the staff problems led to disputes; tenant enthusiasm and cooperation never properly recovered from this earlier disappointment.

Ethnographic research found the Hull experimental estate community to be socially fragmented. The more established tenants had managed to insulate themselves, by and large, from the remainder who were generally more vulnerable to adverse economic and personal experiences and misfortunes. Among the vulnerable tenants could be found a number of crime-prone groups: networks of adults stealing and receiving stolen goods, and unruly teenagers who caused trouble to an extent far beyond their numbers (Foster and Hope 1993). Tenantmanagement-dominated PEPs operated on this estate, leading to the formation of a Neighbourhood Management Committee with directly elected tenant representatives. Additionally, about $£ 3$ million was spent on environmental improvements including damp treatment for dwellings, increasing the security of tower blocks on the estate, and, following tenant consultation, creating greater "defensible space" for about half the houses (Glennerster and Turner 1993).

On the estates studied, the capacity of the PEP model to bring about community organization and reduce crime was affected by the rate of population turnover and degree of social and cultural heterogeneity within the community. On the London experimental estate, residents experienced a greater sense of security and, as found from the victimization surveys, a significant increase in the minority Bengali residents' perception of safety from racially motivated victimization. However, other residents had become poorer, more socially heterogeneous, and 
more disillusioned about tenant participation and the future of their estate (Foster and Hope 1993). Victimization rates declined significantly but not by nearly as much as on the control estate. ${ }^{1}$

On the Hull estate, both the design improvements, and the general sense of optimism generated by PEP's efforts to involve tenants, 'gave support to the more established tenants who began to exude a greater confidence about their estate and its future. Yet, at the same time, a greater number of vulnerable poor were coming onto the estateincluding young, homeless single people, lone parents, and those discharged from social services care or institutions. Social cohesion and "empowerment" increased among many residents as a result of environmental modifications and PEP's efforts to involve them in the improvement of services and estate management. However, many of the newcomers-particularly the young poor who were concentrated in one part of the estate-became extremely vulnerable as victims. Some of the newly arrived young unemployed had considerable difficulty in sustaining themselves independently - both financially and sociallyand became involved in criminal activities of various kinds on the estate. In particular, they seemed to act as a link between existing networks of teenagers and of adults involved in crime on the estate, serving to deepen and widen networks of offending (Foster and Hope 1993).

Overall, outcomes on the Hull experimental estate reflected the interplay of conflicting forces of community control and criminality (Hope and Foster 1992) - there were reductions in victimization from some offenses (i.e., burglary) and in some parts of the estate but increases in other offenses (i.e., theft from vehicles) and in other parts of the estate. There were reductions, relative to the control estate, in residents' worries about victimization; an increasing sense of care and concern for the residential environment; and a reduction in perceptions of litter, graffiti, and other physical disorders (see Skogan 1990) as problems. However, comparison between the surveys showed an increased perception of person-related disorder-including disturbances from youths, noisy neighbors, persons hanging around drinking-and

\footnotetext{
${ }^{1}$ The much greater decline in crime on the control estate may have been due to a combination of good-quality local housing managers-delivering many of the ingredients of the PEP package, increased physical security, and greater community surveillance stemming in part at least from the stabilizing influence of a substantial Bengali community on the estate (Foster and Hope 1993). Generally, the Bengali community in Britain, though economically disadvantaged, is culturally cohesive and has a low offender rate.
} 
indications of diminished disapproval for holding noisy parties, swearing in the streets, and hanging around in groups in public (Foster and Hope 1993). Neither did the rate of resident mobility decline.

Though the pattern of outcomes was complex, this study illustrates the dilemma of the community organization model inherent in the legacy of Shaw and McKay. First, in the London experience, much seemed to hinge on the individual quality of those individuals involved in organizing-something that may be difficult to replicate. Second, as with the CAP experience, the outcomes described here were shaped by forces external to the community. In particular, the Hull experience suggests that efforts at community organizing only weakly, if at all, acknowledged those external, structural forces-particularly poverty, cultural heterogeneity, and residential mobility - which may be increasing, simultaneously, social and cultural disorganization within communities (Kornhauser 1978). In this case, the source of destabilization arose from outside the residential community - that is, the changing pattern of tenant allocation (see Bottoms and Wiles 1986) produced greater numbers of the young poor among newcomers whose arrival significantly altered the social $\mathrm{mix}$ on the estate. Again, outcomes were shaped by changes occurring in the vertical relationship of the estate community to the economy of the wider society (Foster and Hope 1993). Thus, as Bursik and Grasmick conclude (1993, p. 51): "A full understanding of [community] control must also consider the effects of decisions and dynamics based outside the neighbourhood on the nature of relational networks within the community."

\section{Resource Mobilization}

The Chicago Area Project's implementation trajectory may have been determined by the problems of building links with and between community residents; other difficulties of implementing community action have stemmed from attempts to influence the distribution of political power and resources. The contemporary view (Bursik 1988) sees social disorganization as the inability of the community to act together to realize common values (Kornhauser 1978). Yet, as seen above, residential communities may be limited in their ability to get things done for reasons beyond their control (Sampson 1987a). The resource-mobilization model embodies the idea that it may not be sufficient merely to promote social cohesion in communities if they are starved of resources to address the social and economic conditions that 
are undermining that cohesion. In this sense, community action becomes concerned with the transfer of economic and political resources to empower local communities, to give youth a stake in conformity (Toby 1957), and to relieve the frustrations of blocked aspirations and relative deprivation that induce delinquency (Cloward and Ohlin 1960).

The exemplar of the resource-mobilization approach remains the Mobilization for Youth (MFY) program on New York's Lower East Side-the paradigm for the community action programs of the "War on Poverty" in 1960s America (Short 1975). Wilson (1978) comments that the intellectual justification for MFY may have been lacking in view of the absence of hard evidence from controlled experimentation; though in the nature of the political reality of crime prevention paradigms, this omission is hardly damning. Nevertheless, the paradigmatic shift toward resource mobilization seems to have come about through a convergence of trends in at least four separate but related areas: urban structure, urban social policy making, criminological theory, and social work practice.

In the first place, the period between 1940 and 1960 saw an unprecedented, large-scale migration of blacks from the South to the Northern industrial cities following a relatively stable period of population growth after the curtailment of mass European migration in the 1920s. Bursik's (1986) longitudinal study of Chicago shows that the period 1930-40 bears out Shaw and McKay's assumptions about the stability within the urban system of socially disorganized, high-delinquency areas. Yet, in subsequent decades, the ecological distribution of highdelinquency areas within the city follows a general pattern associated with nonwhite compositional change and increases in resource deprivation within certain communities. The Shaw and McKay model assumed a private-market process of competition within the city, but the differential patterns of settlement of black migrants and white residents in later years reflected nonmarket factors (Bursik 1986), particularly racial conflict over access to housing, suburban development, economic and political factors limiting the racial integration of neighborhoods, and the entry of the public sector into the large-scale provision of low-rent housing (Hirsch 1983). Thus the concentration of offenders and poverty in certain neighborhoods was seen no longer to reflect merely the deficiencies of indigenous institutions but the neighborhoods' powerlessness and inability to capture economic resources that the urban process was distributing inequitably. 
The support of the large foundations and the federal government for delinquency prevention through community action reflected two somewhat different concerns. First, there was a new generation of optimistic, social-science-influenced policy makers, subscribing to a new form of government - that is, "experimental social administration" (Moynihan 1969; Halsey 1978); but, second, there was the pressing imperative of dealing with the crisis in urban government occasioned by the discriminatory experiences of the great black migration (Piven and Cloward 1971; Lemann 1991): "The delinquency problem seemed an especially promising issue around which to frame a Federal program. It held out the promise of new services to blacks and, simultaneously, the promise of law and order to whites. The very services that would appeal to the swelling numbers in the ghettos would also assuage the whites who feared the ghettos" (Piven 1969, p. 173). Most important, community action was seen as a way of delivering resources to poor, black urban residents who would otherwise be denied them by existing urban government (Marris and Rein 1972).

Cloward and Ohlin's (1960) analysis emphasized the frustrations of blocked access to success goals through legitimate means as a motivating force in delinquency. Yet, they concluded (pace Wilson 1975) that the traditional outlets for status attainment in slum communitiesrevolving around various forms of organized criminal activity-were also disappearing along with the structure of the older, ethnic slums. Without any outlet for status achievement, they predicted that delinquent adaptations would thus become more predatory and violent in poor areas. Similarly, whereas in the older slums, economic opportunities were delivered via the local political machines, these were being replaced by income maintenance, subsidized housing, and benefit programs administered bureaucratically by state welfare agencies, reflecting also a shift in social welfare thinking away from individualized treatment and counseling (see Kahn 1968). In their view, the replacement of a political process by a welfare-distributive process served to isolate residents of poor communities further from the wider society (Cloward and Ohlin 1960, p. 209). Poor communities would thus have to be mobilized to gain resources in a way that would strengthen their "vertical" linkages with the wider resources of society.

1. Strategy. The Mobilization for Youth approach differed mark-. edly from what had been done before in the treatment of delinquency in community settings (Kahn 1968): it made explicit reference to social science theory; it combined a traditional emphasis on individual adjust- 
ment with a concern to address the structural causes of maladjustment; it received direct funding from the federal government, bypassing local power and patronage; it proposed to engage its professional staff in community action and political campaigning; it aimed to make services relevant to the needs of client groups in their communities; it aimed to take a holistic approach to community problems; and it recognized the possibility of conflict with municipal bureaucracy (Helfgot 1981).

Yet, while its intellectual legitimacy may have derived initially from Cloward and Ohlin's "opportunity-structure" theory, the program in practice emphasized the provision of legitimate economic opportunities for conformity and did not address the control of illegitimate opportunities for crime that the theory had also stressed (Short 1975). Importantly, while opportunity-structure theory set the general objective, it did not provide any particular suggestion as to bow opportunities were to be delivered (Short 1975; Wilson 1975; Helfgot 1981). Indeed, some have argued that the theory actually appeared attractive because of its vagueness about how access to success goals for slum youth might be accomplished-it could give an intellectual imprimatur to a diverse constituency that the idea of community action needed to bring together (Short 1975; Wilson 1978).

2. Implementation. From different vantage points, Marris and Rein (1972), Helfgot (1981), and Lemann (1991) provide vivid pictures of the political ferment of 1960s America in which MFY and the many other programs loosely associated with it were implemented. Mobilization for Youth in practice became susceptible to a diversity of approaches and the incorporation of other objectives (Helfgot 1981). In particular, the program evinced a tension between service delivery, the provision of social, employment, and welfare services that were available for local youth, and resource capture, the mobilization of residents into political action intended to bring down more resources to the inner-city community. Inasmuch as it sought to shift the balance toward empowerment and away from welfare dependency, the program became increasingly involved in political action, displacing the immediate objective of providing services for delinquent youth and moving toward a more general challenge to local sources of political power, in which the mundane aims of crime prevention became subsumed in the broader political struggle. In the end, MFY encountered a severe reaction from municipal and other interests that led to an undermining of its funding and altered the nature of its programs (Fried 1969; Helfgot 1981). Particularly, the emergent political organization of MFY and 
other community action programs came into conflict with existing political structures of city government (McGahey 1986) and lost. With the failure of its effort to capture economic resources for its community, MFY eventually transformed into a less controversial manpower training organization that aimed to equip local youth with the skills required by local employers (Helfgot 1981).

Though Mobilization for Youth has been seen as an exemplar of community action against crime (Short 1975), the history of the period shows clearly how a policy paradigm can mushroom and diverge from the circumscribed experimental mode that its social scientific planners once might have had in mind, especially if it becomes part of a wider political movement. Community action programs were promoted by central government as an effective way of delivering resources directly to the poor-and resolving abiding problems of central-local governmental relations; while program activists saw them as a vehicle for an insurrectionist restructuring of urban power. In an important contrast to CAP, action focused primarily along the vertical dimension of power, with little attention paid to building community institutions in the ghetto that might have delivered resources to local youth. Yet "the war on poverty was a political failure mainly because it made enemies of local elected officials. Its main program, community action, was a conceptual failure in the sense that it raised expectations about the revival of the ghettos that couldn't be met" (Lemann 1991, p. 344).

Community groups still try to address "social problems" in impoverished, high-crime communities (Podolefsky and DuBow 1981). Skogan (1988) has dubbed these "insurgent groups." As he points out (Skogan 1988 , p. 9), insurgent groups "like all organizations . . . need to articulate their members' concerns and win victories that generate benefits for their constituents." Their priorities are much more likely to focus on bringing economic, health, and social opportunities or benefits to the community than in specifically anticrime activities. Insurgent groups tend to see crime as a consequence of their community's lack of resources (Podolefsky 1983) and therefore, inasmuch as they are concerned with crime, focus on addressing its root causes in joblessness, poverty, poor housing, and discrimination (McGahey 1986). In bringing job programs, clinics, youth training, or investment to their communities, such groups strive to redistribute urban economic resources-again focusing on developing vertical linkages with wider sources of power.

Yet there is also a dilemma familiar to community groups: whether 
to preserve the momentum of campaigning, though remaining in a conflictual and marginalized relationship with the sources of urban power; or whether to become the recipients and administrators of much-needed resources, through changing the relationship with the community to that of service provider-and thereby becoming an adjunct of government, and possibly complicit with the dominant political interests that the groups once opposed (Skogan 1988). Even so, the scale of resources made available by such a compromise may be less than might have been anticipated or needed. Rosenbaum (1988a), for instance, points to the problem of "dosage"-that resources actually made available for community programs-especially those seeking to address social conditions-are often so meager that little might reasonably be expected from them.

Probably the only politically feasible resource-mobilization strategy in recent years has been that of encouraging community self-belp-of attempting to leverage public and private resources to develop community-based enterprises and training programs for high-risk youth. During the 1980s, the Eisenhower Foundation supported ten nonprofit community organizations in poor urban neighborhoods to "empower local organizations to take the lead in defining anticrime strategies best suited to their own capacities and the specific problems and conditions of their communities. . . . Organizations were free to emphasize youth empowerment over opportunity reduction, or vice versa. . . . Each group was required to develop financial self-sufficiency in the sense of creating an ongoing mechanism to continue the program for at least twelve months after the initial . . s support had ended" (Eisenhower Foundation 1990, p. 19). Eight of the ten implemented work programs that had been developed during the planning process. Two organizations focused exclusively on services for individual youth referrals; the other groups selected either opportunity reduction or "causes of crime" strategies-with only three opting for a balanced approach (Lavrakas and Bennett 1989). Nevertheless, the type of strategies adopted, and the level of implementation effort, seemed to have more to do with the organizational capacity of the community groups-including the orientation of their directors-than with their host community's responses to the groups. Consequently, the evaluators conclude that "the capacity of a 'bubble-up' planning approach . . . to generate increased community participation is uncertain" (Lavrakas and Bennett 1989, p. 66). Additionally, it is unclear whether the goal of such programs was to change the social structure of their neighborhoods or to provide 
services for individual high-risk youth, albeit in a community setting (Rosenbaum 1988a).

3. Evaluation. Not surprisingly, the essentially political process of the resource-mobilizing strategy of MFY and similar programs did not occasion any assessment of its impact on delinquency, a goal that seems to have disappeared in the process of politicization. The evaluation of the Eisenhower Program concluded that "despite the many strategies that were implemented across the sites, the impact evaluations provide little evidence that the . . . Program had documentable successes in achieving its major goals of crime reduction and improved quality of life, although there was some consistent evidence . . . [of] . . . a slight reduction in residents' fear of crime in several of the sites. Many positive changes that were noted in site-specific evaluations were relatively small and patterns of positive change at the sites were not consistent enough to support stronger conclusions" (Lavrakas and Bennett 1989).

In terms of their impact on general community change, the Eisenhower projects may simply not have been of sufficient scale or magnitude to overcome the severity of the problems in the high-crime neighborhoods in which they were targeted (Lavrakas and Bennett 1989) - the problem of the necessary "dosage" of intervention (Rosenbaum 1988a). The dilemma of the resource-mobilization approach, therefore, may be that asking for too much may provoke a reaction, while getting too little may have negligible effect.

The long-term impact of MFY has been primarily by virtue of the reaction it provoked: it was seen as illustrating the significance of the vertical dimension of power in local communities and the inability of community institutions to alter the social structural conditions that were held to give rise to delinquency. However, and, as it turned out, of more significance for governmental crime control policy in both America and Britain, the experience was interpreted as evidence of the folly of constructing policy on the vaunted and unsubstantiated promises of social analysis (Moynihan 1969). This argument was developed by James Q. Wilson (1975) in his influential critique of liberal crime control policy and coalesced into the prevailing mood in social policy during the 1970s that Wildavsky (1980) has termed the "strategic retreat on objectives." Thus while Wilson (1975) might concede that antipoverty programs and breaking up the ghettos might be desirable in their own right, the apparent inability of the programs that were implemented to reduce the escalating crime rates of the 1960s was held to show that social programs were not an effective means of crime 
control and that policy should adopt alternative strategies aimed at raising the costs of engaging in crime and of reducing the opportunities for illegitimate behavior (see Clarke and Cornish 1985).

Nevertheless, whatever may have been the reality of community action programs-whether they were underresourced and destroyed by vested power interests or were the irresponsible raising of false expectations based on unsubstantiated theory (Wilson 1975)-the experience came to take on an almost mythical character during the rise to political ascendancy of conservatism in America and Britain. In the process of constructing a new paradigm, described in the:next section, the fate of community action-and its inappropriateness for crime control-may have come to take on a greater significance than it may ever have had in reality: "Rhetorically, the war on poverty was made to sound more sweeping than it really was, and so set itself up [or was set up ] to seem as if it had ended in defeat when it didn't vanquish all poverty" (Lemann 1991, p. 344), or crime for that matter.

II. Community Crime Prevention in the Frightened City During the 1970 s, the crime problem in urban communities was redefined significantly in public policy making. This led to a sustained focus on community crime prevention, first in the United:States and later in Europe. A new paradigm emerged, that of residential defense. While it aspired, like the earlier paradigms, to change the conditions of residential communities, it reflected a new policy concern about crime in the urban environment, specifically the self-policing of communities. Two strategies emerged during the 1970s to promote citizens' informal self-policing: the intentional organizing of community surveillance, and environmental modification to encourage more natural surveillance.

\section{A. Intentional Organizing of Community Surveillance}

By the 1970s, public discourse-particularly in America-was seeing the city as an increasingly dangerous place to live; an.image was developing of urban residents afraid of falling victim to crime and concerned about "the standards of right and seemly conduct in the public places in which one lives and moves" (Wilson 1985, p. 28). Increasing public anxiety about rising crime rates in late-sixties America prompted a redefinition of crime as a major civil and political problem. The President's Commission on Law Enforcement and Administration of Justice (1967) marked a turning point, elevating the 
problems of victimization, and the fearful anticipation of it, as concerns of crime policy and urging that local communities should be supported in crime prevention efforts. This general shift in policy-the "victimization perspective" (Lewis and Salem 1981)—resulted in progressively greater legislative and funding support during the 1970s in America for the active involvement of citizens in the maintenance of order in their residential environments (Lavrakas 1985).

Whereas social order in communities was preserved, in Shaw and McKay's model, through the inculcation and maintenance of norms of conduct, primarily through the socialization of the young-and in the resource-mobilization model by ameliorating youth's frustrations at the absence of economic opportunities - the victimization perspective now focused on citizens becoming anxious about safety from the threat of predatory victimization in their home environment (Conklin 1975). The fundamental imagery had been supplied by Jane Jacobs (1962): cities serve a diverse range of interests and purposes, at once liberating but also troubling for residents because their size and complexity encourages anonymity and continually brings strangers into contact who may be dangerous because they share no common bonds of culture or kinship (see also Wirth 1938).

Jacobs believed that modern urban planning, especially the differentiation and segregation of residential environments from other land uses, was undermining residents' ability to cope with and regulate urban diversity. Paradoxically, the planned correction of the ills of the slums identified by the Chicago School-the invasion of residential areas by commercial land uses, residential proximity to transport routes, the engineering of the social composition of communities-had been incorporated as basic tenets of postwar city planning and urban renewal. The considerable involvement of municipal government in managing, planning, and building cities and providing housing environments was now being seen as misguided, primarily because such planning obstructed the basic means by which order was maintained: "The first thing to understand is that the public peace-the sidewalk and street peace-of cities is not kept primarily by the police, necessary as the police are. It is kept primarily by an intricate, almost unconscious, network of voluntary controls and standards among the people themselves, and enforced by the people themselves. . . . No number of police can enforce civilization where the normal, casual enforcement of it has broken down" (Jacobs 1962, p. 41).

The key to urban safety was thus seen as residents regaining informal 
social control over behavior in the public places of their neighborhoods (Greenberg, Rohe, and Williams 1985). How this was to be achieved was mainly through natural surveillance-day-to-day supervision by residents of their environment "employing the full range of encounter mechanisms [e.g., questioning strangers, in-person surveillance, intervention, calling the police] to indicate their concerned observation of questionable activity and their control of the situation" (Newman 1973, p. 4). The objective, then, was to strengthen communities' informal defenses against predation by strangers which the urban environment was impeding.

The view that urban social order could be maintained by citizens' informal self-policing of their own communities had considerable political attractiveness (Skogan 1990). At the level of expediency, it provided one answer to a growing crisis in the perception of police effectiveness, stemming both from an accumulation of research evidence (Clarke and Hough 1980) and popular reaction to rising rates of crime; it offered a promise of "doing more while spending less"-a lower-cost solution to crime control than criminal justice or social program expenditure during a period of budgetary cutbacks and fiscal restraint (in American cities during the 1970s and in Britain during the 1980s); it offered a way of dealing with property crimes that surveys suggested were the most commonly experienced and that prompted the most widespread worry (Clarke and Hope 1984); and it offered modest support for communities while diverting attention from claims to address the root causes of crime. At the level of ideology, it appealed to conservative concerns about the maintenance of standards of behavior (Wilson 1975) and to growing libertarian instincts about the importance of voluntarism, self-help (Lavrakas 1985), the role of the "active citizen," and the minimal role of the state (Brake and Hale 1992).

1. Strategy. Intentional organizing embodied a two-fold expectation: first, that organizing communities into collective crime prevention projects would have a direct preventive effect on crime (by increasing natural surveillance) and on fear (through joint participation); and second, that participation would indirectly reduce crime and fear through increased social interaction, a stronger sense of community solidarity, and thus more effective informal social control in the neighborhood (DuBow and Emmons 1981). A wide range of collective crime prevention projects were suggested as vehicles for neighborhood self-policing (Feins 1983), though most attention focused on the "big three"-block watch, security surveys, and property marking (Titus 1984)—which 
in turn have!become subsumed under the general rubric of neigbborbood watch - that is, informal organizations of residents who agree to watch over each others' property and report suspicious activities to the police. Encouragement for the idea of block or neighborhood watch had come from an evaluation of the Community Crime Prevention Program in Seattle that suggested that participants in small block watches (who were also provided with security advice and property marking) had reductions in their risk of burglary without evident displacement to nonparticipating households and areas (Cirel et al. 1977).

2. Implementation. Residential defense was given substantial political support during the 1970s in America and in the 1980s in Britain. In the United States, federal funding by congressional mandate supported a range of programs to encourage both intentional organizing and environmental modification-the latter often referred to as "Crime Prevention through Environmental Design" (CPTED; see, e.g., Fowler, McCalla, and Mangione 1979; Wallis and Ford 1980; Fowler and Mangione 1982). Descriptions and reviews of these programs can be found in Skogan (1988), Lavrakas (1985), and McPherson and Silloway (1981). In Britain, the approaches were disseminated through the Home Office's long-term program of research and development in crime prevention (Clarke and Mayhew 1980; Heal and Laycock 1986), within the British police (Bennett 1989a), and later by central government (Central Office of Information 1989), local government, and the Crime Concern organization (Bright 1991). Major difficulties of implementation have been encountered both in program design and in specific applications of the intentional organizing approach. Three key implementation problems have been encountered-differential participation, program initiation, and program maintenance. Excellent summaries of the research on these three issues are available (Rosenbaum 1987, 1988a; Skogan 1988, 1990), and only the main points are rehearsed here.

3. Differential Participation. A variety of studies offered two major findings. First, members of community anticrime groups are more likely to be better-off, more educated, longer-term residents who are married, have children, and own their own homes. Second, anticrime groups are :least likely in low-income, heterogeneous, deteriorated, renting, high-turnover, high-crime areas (Skogan 1988).

Studies of individuals participating in community crime prevention groups suggest that their profile is very similar to those who participate in any kind iof voluntary activity (Rosenbaum 1988a; Skogan 1988). 
And surveys suggest that community volunteers differ from the rest of the population, having greater identification with local concerns (e.g., among owner-occupiers and families with young children), more social confidence and competence (e.g., excluding the young, the old, and the poor), and more free time (e.g., including the middle-aged and excluding families where both parents work and single parents [Hope 1988a]). Owner-occupation seems especially salient: Lavrakas (1981) found home ownership to characterize households who were likely to take any kind of crime prevention measure. When this is extended to collective participation in crime prevention, homeowners may have a greater commitment to maintaining the standard of the neighborhood through their personal incentive to maintain house prices and have greater freedom and responsibility than renters for taking prevention measures.

Studies of the low level of community organization in poor, crimeridden communities suggest that residents are "deeply suspicious of one another, report only a weak sense of community, have low levels of personal influence on neighborhood events . . . and feel that it is their neighbors whom they must watch carefully" (Skogan 1988, p. 45). Mutual suspicion and lack of trust in high-crime communities may therefore undermine community anticrime efforts, particularly those like neighborhood watch that require members to exchange information about themselves (Podolefsky and DuBow 1981).

Unfortunately, these two sets of findings do not indicate whether participation (and thus, by extension, effectiveness) is a function of social composition or community context. Some areas may have a low level of participation because they contain more people who are not inclined to be participants (i.e., a social composition explanation). Or, it could be that the nature of life in certain areas, or the character of communal association, is not conducive to forming or sustaining voluntary groups, despite the inclinations of individual members (i.e., a community context explanation). If it is assumed that policy makers are keen to see the approach implemented on a wide scale and believe it is possible for communities to be organized deliberately, then it is important to know whether differential participation is a compositional or contextual problem. If the former, then there is some promise that additional organizing efforts might overcome the obstacles of communal association to reach the people. If the latter, then participation will always be partial, no matter how much organizing effort, unless the social structure of such communities is altered. 


\section{TABLE 1}

Participation in Neighbourhood Watch, England and Wales, 1984-88, Percentage of Households Living in Areas Classified as Belonging to Each ACORN Group

\begin{tabular}{lcc}
\hline ACORN Group & $\begin{array}{c}\text { Affluent } \\
\text { Suburbs }\end{array}$ & $\begin{array}{c}\text { Poorest } \\
\text { Council } \\
\text { Areas }\end{array}$ \\
\hline $\begin{array}{l}\text { 1984:* } \\
\text { "Supporters" } \dagger\end{array}$ & 64 & 58 \\
$\begin{array}{l}\text { Households burgled (including attempts) } \\
\text { 1987: }\end{array}$ & 3 & 12 \\
$\quad$ Estimated participants & 10 & 5 \\
1988: & & 13 \\
Scheme setup in area & 29 & 7 \\
Members & 24 & 57 \\
Participation ratell & 84 & 13 \\
Households burgled (including attempts) & 3 & \\
\hline
\end{tabular}

Nore.-ACORN is a small-area geodemographic classification system based on the 1981 United Kingdom Census (see Hough and Mayhew 1985, app. F).

* Source: 1984 British Crime Survey (Hough and Mayhew 1985, table 12).

$\dagger$ The percentage of respondents who said they thought Neighbourhood Watch would work in their area and who were personally prepared to join, after having read a description of the concept (see Hope 1988a).

$\ddagger$ Source: Hussain (1988, table 3.3).

§ Source: 1988 British Crime Survey (Mayhew, Elliott, and Dowds 1989, table 15).

"The percentage of members among those who said a Neighbourhood Watch scheme was operating in their area (source: 1988 British Crime Survey [Mayhew, Elliott, and Dowds 1989, table 15]).

Separating the compositional (individual level) from the contextual (communal level) reasons for nonparticipation is confounded by two likely phenomena: first, the housing market tends to differentiate people according to class and income, so that like people will more likely than not live together (Bottoms and Wiles 1986); and second, participation is a function of both inclination and opportunity (Skogan 1988). Few people will be inclined to participate if there are no available opportunities or if they judge the prospects of successful community organization in their neighborhood to be poor. Likewise, people may not voluntarily organize community groups where they judge other community members to be unreceptive.

Table 1 illustrates these issues, reporting survey data tracking the development of Neighbourhood Watch (NW) in England and Wales. 
Two different kinds of social area are displayed—affluent suburbia, and the poorest council estates (public housing projects)-with differing levels of crime (see, generally, Hough and Mayhew 1985; Hope and Hough 1988). In 1984, although less than 1 percent of households interviewed in the 1984 British Crime Survey (BCS) belonged to a scheme, most people polled ( 89 percent) thought NW would be effective against burglary; yet over a third of all BCS respondents said they would not join a scheme-and the proportion did not differ substantially between the two very different kinds of area (table 1). Table 1 shows a survey of NW coordinators that estimates that, by 1987, residents of affluent suburbia were twice as likely to be members than were residents of the poorest estates, despite still relatively low levels of participation generally (Husain 1988). By 1988, the BCS confirmed that 90 percent of all respondents had heard of the idea, and while still only 14 percent of households said they were members, two-thirds of nonmembers said they would be willing to belong (Mayhew, Elliott, and Dowds 1989). Nevertheless, table 1 shows more schemes established in affluent suburbia, covering a greater proportion of the population, than in the poorer area. Moreover, differences in the participation rate show that, even where the opportunity to participate was available, fewer residents of the poorer area were taking it up. The findings in table 1 suggest, then, that both area and individual obstacles to participation exist.

Comparisons between members and nonmembers suggest that the type of neighborhood still has an effect on participation, after controlling for individual differences; but so also do individual differences, after controlling for neighborhood type (Hope 1986a; Skogan 1988; Mayhew, Elliott, and Dowds 1989). Bennett (1989b), for instance, found that participants had different characteristics than nonparticipants within areas that had neighborhood watch schemes. As regards the argument that making opportunities available for participation will overcome individuals' reluctance to participate, differences between "supporters" and others in England and Wales before the mass introduction of neighborhood watch (Hope 1988a) closely resemble differences between actual participants and others after considerable national effort at disseminating the idea (Mayhew, Elliott, and Dowds 1989, p. 54, n. 7). It may also be hard to get agencies to invest effort in organizing poor, heterogeneous neighborhoods: the police-based Community Organizing Response Team in Houston held most of its community meetings in the part of the target area dominated by owner-occupied, 
single-family homes, with little effort extended to the poorer section of the area containing blacks in rental accommodation (Skogan 1990).

Perhaps the most comprehensive test of whether individual reluctance to participate disappears given the availability of opportunities comes from the "Minneapolis Experiment" where, despite substantial block-level organizing efforts, participation was still low (Rosenbaum $1988 b$ ), and "even though program effort was greatest in poorer, black, and higher-crime areas, attendance at meetings was highest in white and middle-to-upper-income areas where crime problems were not substantial" (Rosenbaum 1988b; Skogan 1990, p. 148). The obstacles to participation would not seem solely for want of opportunities available in neighborhoods but also stem from the different orientations of low-income, renting, and nonfamily social groups.

4. Program Initiation. Natural histories of community crime prevention groups are sparse, and relatively little is known about the specific factors affecting their origin, maintenance, and longevity. Some research suggests that, while community members may form some inclination to "do something" in response to an increasing perception of neighborhood problems, they may also become incapacitated from taking organized action if problems become too severe and, likewise, may only become prompted into action if they are, and remain, otherwise satisfied with their neighborhood; but these findings are only inferential (Hope 1988a). While community groups may form around a particular criminal cause célèbre in the neighborhood, they seem equally likely to emerge for other reasons, and to be concerned about other problems in the community, in addition to, or instead of, crime (Skogan 1988).

A key policy question addressed in the literature is whether anticrime groups can be engineered-either by transplanting crime concerns onto existing community organizations or by implanting anticrime groups into neighborhoods that do not have them (Rosenbaum 1988a). From the perspective of central government funding, if the experience of the resource-mobilization paradigm turned into a political quagmire, American federal support for community self-help turned into an administrative quagmire (Skogan 1988). Perhaps as a reaction to the loss of political and financial control experienced during the resourcemobilization paradigm, tight administrative controls in this era seem to have strangled voluntarism, imposing considerable burdens of grant administration on local organizations and deterring fledgling and unsophisticated self-help groups (McPherson and Silloway 1981). Similarly, 
concerns for political stability sent the bulk of the money to "noncontroversial organizations and uncontroversial proposals" (Skogan 1988).

Manipulating concern about crime as a stimulus for group involvement in crime prevention is also an uncertain strategy. While there may be little point in attending meetings about a problem that does not exist, or is seen as much less important than other issues (Hope 1986a), an overemphasis on crime may be equally aversive. A careful evaluation of an effort to get community groups to organize block watches in Chicago found that participants came away more worried about crime, presumably because the constant focus on local crime problems undermined rather than reinforced their sense of community well-being (Rosenbaum, Lewis, and Grant 1986; Lewis, Grant, and Rosenbaum 1988). Raising crime consciousness of citizens or community groups may be pointless anyway. DuBow and Podolefsky (1982) found that 87 percent of respondents to a citizen survey already agreed with the general idea that neighborhood groups could reduce crime, a view shared equally among participants and nonparticipants.

5. Program Maintenance. Paradoxically, successful programs of "watching" may also contain the seeds of their own destruction. Looking out for crime that does not happen may be nearly as boring as watching paint dry, while the surreptitious nature of most property crime may evade those active citizens intent on catching wrongdoers in the act. Even though the Minneapolis Experiment found greatest success with the more affluent residents, attendance at meetings rapidly tailed off, largely because there were no real problems to deal with (Skogan 1990). The longevity of neighborhood watch schemes may have most to do with their not requiring much of participants in practice. In Britain, the most common activity of neighborhood watch members appears to be putting a sticker in the window, and only about a quarter had attended any meetings following the initial launch (Mayhew, Elliott, and Dowds 1989; see also Bennett 1990).

While members seem more likely to report incidents to the police than would comparable nonmembers, similar proportions are likely to witness crime in their area (Mayhew, Elliott, and Dowds 1989). Presumably, neighborhood watch is intended to increase the natural surveillance of a community in addition to making it more efficient, but there are two reasons why this may prove difficult. First, although people do seem to behave in ways consistent with natural surveillance (Shapland and Vagg 1988), people may also fail to notice crime taking place, have difficulty in deciding whether a crime has been committed, 
be reluctant to intervene, be reluctant to call the police, and be unable to identify the suspect subsequently (Mayhew et al. 1979). Additionally, since over half of all dwellings in England and Wales are likely to be unoccupied for three or more hours a day (Hope 1984), there may simply be little scope or advantage in appreciably raising the level of natural surveillance in residential communities (Mayhew et al. 1979). Second, most members (41 percent), reporting in the British Crime Survey, feel that the greatest benefit of participation is having one's home watched-only 13 percent thought it improved neighborliness (Mayhew, Elliott, and Dowds 1989). However, since "watching" is voluntary, there will likely be no monitoring of whether people actually do watch out as they are supposed to and thus no sanction imposed-for example, withdrawal of the watching benefit-if they do not watch out at all. In other words, the voluntary nature of neighborhood watch contains a powerful incentive for "free riding" (Hope $1988 b$; Field and Hope 1990), which, if enough people do it, can negate the actions of those who do not (see Olsen 1965).

Summarizing, Skogan notes that, for the survival of community crime prevention initiatives, "the critical factor is the decision by multipurpose organizations to add crime prevention to their agenda. Participation levels are high in areas where organizations are successful and attract members. Most successful organizations have complex agendas; few of them were originally organized around crime concerns, and people join them for a variety of reasons revolving around their stake in the community and their citzenly instincts. It is when these groups take on crime prevention that participation in anticrime activities is high" (Skogan 1988, p. 54).

6. Evaluation. In view of the theoretical and implementation problems noted above, it is perhaps not surprising that evaluation research has not demonstrated much in the way of impact on crime for the community defense paradigm. Despite many reported claims for success, relatively few reliable program evaluations have been completed (Lurigio and Rosenbaum 1986). Evaluation research on the impact of neighborhood watch, with reliable research designs, has been carried out on programs in Seattle (Lindsay and McGillis 1986), Chicago (Rosenbaum, Lewis, and Grant 1986), Minneapolis (Skogan 1990), and London (Bennett 1990). Yet none of them have demonstrated reductions in community crime rates, and the benefits to participants reported initially in the Seattle project (Cirel et.al. 1977) had disappeared after eighteen months (Lindsay and McGillis 1986). Improvements in 
fear levels and community cohesion in these programs were few and sporadic.

British government support for community crime prevention during the 1980s was couched often in terms of rational self-interest: "Protecting your own home is fine, but you will enjoy greater security if every one around you is working at it" (Central Office of Information 1989, p. 26). However, a purely rational-choice interpretation of the above evidence would suggest that, were individuals to make such a calculation, they would, in many circumstances, choose not to participate (Field and Hope 1990). This outcome is more likely under four conditions. The first is when the perceived costs or risks of voluntary participation outweigh its apparent benefits-that is, the poor residents of high-crime communities have few personal resources to donate to voluntary activity, feel they face considerable risk in contacting neighbors whom they perceive to be dangerous (Merry 1981), and may have little personal or (as renters) financial stake in the neighborhood. The second is where neighborhood commitment has opportunity costs-for example, distracting from effort that might otherwise be spent in pursuing opportunities or accumulating resources to be able to move away. The third is where marginal additions of participation are perceived not to produce commensurate reductions in risk-no matter how much effort, neighborhood crime is unlikely to disappear, and residents still have to pay for the police, in one way or another. The fourth is where "free riding" obtains the benefit of safety at little or no cost to the individual.

Though politically attractive, efforts to get individuals to give themselives voluntarily to communal activity, where the principal benefit is seen as a reduction in their own risk of crime, does not seem to be a viable crime-prevention strategy, particularly in high-crime communities. The volume of research findings suggests that at the heart of the problem lies the paradigm's reliance on voluntarism as the guiding principle of communal activity. The policy of using citizen self-help as an antidote to the fear of crime paradoxically gave priority "precisely to those activities made impossible by the isolation of individuals living in the communities to be assisted" (Lewis 1979, p. 176). Implementation of the intentional organizing approach appears circular, given the reliance on voluntarism implicit in the model. Differential inclinations toward participation affect the formation and maintenance of organizations, but the availability of organizations-and the resources within the community for establishing organizations-affect the likelihood 
that citizens will participate. "Voluntarism" is differentially distributed among the community; and voluntarism itself makes it difficult to promote and sustain membership or activity. Either way, the residents of poor, high-crime communities end up with fewer anticrime organizations than do more affluent, lower-crime neighborhoods.

\section{B. Environmental Modification}

The idea that the residential environment itself might be changed to promote informal social control stems, in large part, from Jane Jacobs's analysis of cities but captured popular attention through Oscar Newman's theory and proposals for defensible space (Newman 1973). For Newman, the key to improving informal social control by natural surveillance lay in the extent to which residents felt they identified with their environment (i.e., territoriality): "Improved surveillance operates most effectively when linked with the territorial subdivision of residential areas, allowing the resident to observe those public areas that he considers to be part of his realm of ownership and hence responsibility" (Newman 1973, p. 79). Neither the causes nor the behavior of residential defense were taken to be problematic by Newman: defensiveness sprang from latent territorial tendencies common to all human groups. Nevertheless, the design of some built environments-especially mass public housing projects-prevented natural surveillance and defensiveness from expressing itself. Appropriate design would remove these obstacles, and residential control would reassert itself naturally (Hope 1986a).

1. Implementation. Despite policy support for the environmental model, there have been few purposive attempts to implement defensible space design changes on a sufficiently large scale and evaluated with enough rigor to control for alternative hypotheses and confounding influences. In part, this may have been due to the confusing nature of the theories and research findings generated by and in the wake of Newman's (1973) original research (Hope 1986a) and the complexity of conducting reliable research to isolate the various hypothesized effects (Rubenstein et al. 1980). There were also, inevitably, implementation problems, particularly affecting the federally funded American CPTED program managed by the Westinghouse Corporation: "Each of these demonstrations required the co-ordination of several local agencies, and it was quickly learned that the local political environment often determined what, if anything, would be done as part of the demonstration ... the research suggested that modification of the 
social environment was as important, if not more important, than modifications of the physical environment" (Lavrakas 1985, p. 100). In particular, there appears to be no available published: record of what actually happened to the CPTED demonstration proposed for a residential area.

Scale and timeliness also played a significant part. in staying the hand of government from implementing environmental modification programs. Newman's diagnosis of the problems was essentially ex post facto. The mass public housing projects for the most part had already been planned and built, and the onset of restraint in public spending in both Britain and America from the mid-1970s limited additional main program expenditure on public housing, other than perhaps to justify the demolition of the worst examples-for example, the PruittIgoe projects in St. Louis, Missouri. Likewise, the political mood has militated against the provision both of public housing and of government-mandated planning. The policy rather appears to have been one of disseminating the "design solution" among local urban planners and designers in the hope that it might be implemented as and when the opportunity arose. Alterations to the physical environment for crime prevention purposes have thus tended toward relatively low-cost options: improving the security of individual dwellings, beautification and clean-up programs, improved street lighting, and installation of access-control and surveillance technologies (Safe Neighbourhoods. Unit 1993a, 1993b).

2. Evaluation. There is now an extensive review literature on the possible relationships between crime and the physical environmentincluding the concept of "defensible space" (Mayhew 1977; Rubenstein et al. 1980; Taylor, Gottfredson, and Brower 1980; Poyner 1983; Hope 1986a; Taylor and Gottfredson 1986). Following Newman's (1973) assumptions about the "naturalness" of residential defensiveness being unlocked by appropriate design, much subsequent researchincluding that of Newman himself (Newman 1980;, Newman and Franck 1980) - has been concerned to establish the relative independent and conjoint influences of the social and physical causes of informal social control on crime (Hope 1986a). Much of the research, though, has been correlational and suffers from a variety of confounding possibilities that have not been addressed adequately (Taylor and Gottfredson 1986). Chief among these omissions are the failure to test the linkages in the model-that is, that design promotes natural surveillance and that natural surveillance deters crime; failure to differenti- 
ate the "environmental effect" as it influences the perceptions and behaviors of offenders from its influence on resident "defenders"; and failure to take into account the prior allocative processes that assign potentially "criminogenic" populations to supposedly "criminogenic" environments (Hope 1989).

The multicausal confusion surrounding the environmental modification model has been replicated in the multidimensional nature of most programs, so that it has been difficult to isolate for evaluation the dynamics of the design effect. The Hartford Experiment during the 1970s-in the Asylum Hill neighborhood of Hartford, Connecticutillustrates such ambiguities (Fowler, McCalla, and Mangione 1979; Fowler and Mangione 1982, 1986; Taylor and Gottfredson 1986). Here, a combination of street closures and modifications-intended to reduce the accessibility of the area to outsiders-along with localized policing and community organizing, appeared to promote community cohesion, neighborhood satisfaction, and feelings of safety from crime, despite no long-term change in levels of burglary and robbery. The piecemeal introduction, removal, and likely duration of impact of each of the three elements makes it hard to interpret these findings.

It might seem that residents' perceptions of safety and social cohesion can be altered without affecting the community crime rate. Research on the interrelationship between residents' perceptions of crime and their perceptions of other neighborhood values and amenities (including house prices) suggests that "the critical issue is whether victimization is thought to be a low-probability random event or whether it is seen as one element in a class of threatening events thought to occur commonly in an area ... the level of threat is then judged against one's standard-the amount of inconvenience one is willing to tolerate given the other amenities in the neighborhood" (Taub, Taylor, and Dunham 1984, p. 180). By contrast, the results from Hartford might merely indicate a lag between changes in crime levels and residents' perceptions or the dilution of direct police surveillance and organized natural surveillance that also occurred over time (Taylor and Gottfredson 1986).

In a similar vein, while recent reviews of the effectiveness of street lighting in reducing crime have engendered controversy in Britain (see Ramsay 1991), the weight of evidence with regard, at least, to fear reduction in residential areas has generally been supportive of earlier assessments (Tien et al. 1979) - that better lighting does help residents, especially the more vulnerable groups, to feel safer in the public places 
of their residential neighborhoods (Painter 1992). In the PEP experiment on the Hull estate, described in Section I, the greatest relative reduction in burglary occurred in that part of the estate where the houses benefited from environmental modifications intended to reduce public access; this was accompanied by a significant increase in residents' territorial attitudes and a marked decline in tenant turnover (Hope and Foster 1992). However, residents in another part of the estate-which had yet to receive these environmental measures-also experienced similar, though less marked, improvements. In the latter case, it is unclear whether this increase in community safety was due to better housing management and consultation or to an anticipation of the benefits yet to come of the environmental modifications (see Clarke 1992).

In general, the evaluation of the possible independent effect of environmental modifications has been confounded by two issues. The first are interrelationships among design, perceptions of community, control behavior, residents' social circumstances, fear of crime, and actual levels of crime, which make it extremely hard, both theoretically and in empirical research, to disentangle 'pure' environmental effects. The second is that there is rarely a practical example of a purely environmental modification that was not accompanied by, or in turn created, other changes that might also have had an impact on crime rates (see Hope and Foster 1992). As Taylor and Gottfredson (1986) conclude, "Simple effects of physical environment on crime range from small to moderate. . . . It appears that alteration of physical environment features cannot have stand-alone crime prevention effectiveness. Resident dynamics are the key mediators of the environment-crime linkage" (quoted in Bottoms and Wiles 1988, p. 86). Nevertheless, the Department of the Environment for England and Wales has sponsored recently the Design Improvement Controlled Experiment to implement some post-Newman design proposals (Coleman 1985), whose evaluation research design may be able to isolate some of the hypothesized effects of environmental design on informal community control and, hence, on crime (Riley 1992).

\section{Community Crime Prevention in the Disintegrating City}

This section considers two more recent views on community prevention that seem to be succeeding the community defense paradigm. Both, in different ways, are reactions to a perceived disintegration 
of order in urban residential communities. Neither, however, directs attention toward the reasons for urban disintegration-though some of these are discussed in Section IV-choosing to concentrate more on controlling its manifestations.

Each approach stems from a relatively recent insight about highcrime areas. First, communities with high crime rates also have high levels of disorderly public behavior or "incivility" (Skogan 1990). This leads to the possibility that preserving order in communities might be a way of reducing their crime rates (Wilson and Kelling 1982). Second, victimization from crime is not only very unequally distributed across residential areas (Barr and Pease 1990) but also unequally distributed among residents within high-crime areas (Trickett et al. 1992). This insight leads to the possibility that the problem of high-crime communities is, in fact, a problem of a concentration of highly vulnerable individuals and households and that such rates can be reduced by targeting effort not on the community as a whole but on its most vulnerable : members (Pease 1993).

\section{A. Preserving Order}

Areas of poverty and residential instability not only have high crime rates but are also more likely to have high levels of social and physical disorder as perceived by their residents-for example, noisy neighbors, loitering youths, drug dealing, vandalism, trash, and so forth (Skogan 1990). American and British data suggest that community levels of disorder are also related to levels of victimization, though residents' perceptions of disorder more strongly influence their fear of crime than the level of victimization itself (Hope and Hough 1988; Skogan 1990). In general, it seems, neighborhood disorder is interpreted as the outward and visible sign of community problems, including a loss of social control (Wilson and Herrnstein 1985). However, the process by which a community comes to acquire an identity or label-neigbborbood coding - may be the crucial intervening factor in translating residents' dissatisfaction with disorderly behavior into actual neighborhood deterioration.

The significance of disorder for neighborhood change appears to rest in its negative effect on residents' satisfaction with their neighborhood (Hope and Hough 1988; Skogan 1990). Taub, Taylor, and Dunham's (1984) study in Chicago suggests that residents' dissatisfaction with their neighborhood, fueled by perceptions of disorder and crime, 
prompts them to compare their communities with others where they might reasonably expect to live. If house prices and amenities in their present neighborhoods are valued, residents might be prepared to stay and tolerate a higher level of crime, fear, and disorder. Otherwise, they may determine to leave if they can. Essentially, this may involve a weighing of the neighborhood's "use value"-that is, the intrinsic values of residence in a particular locale-against its "exchange value" - that is, how properties in the neighborhood are valued in the urban market (Logan and Molotch 1987). Once a number of residents start to leave a neighborhood, departure becomes contagious, for other homeowners perceive a loss in their investment should they choose to stay (Taub, Tayjlor, and Dunham 1984). The stigma of negative neighborhood coding reduces the relative attractiveness of the area to prospective newcomers, housing values decline, and poorer people move in. The remaining residents, whose tolerance of newcomers may be lessened (or whose fear may be heightened) through associating them with neighborhood problems, also want to leave, particularly as the neighborhood housing stock adjusts to the lower-income market, including a shift toward rental tenure, the multioccupation of dwelling units, and a reduced level of investment in the housing stock (Skogan 1986). This further fuels the spiral of socioeconomic decline, concentrating the poor even more in such areas and, as noted above, reducing further the community resources for self-regulation.

In this respect, it perhaps matters less what the original reasons for disorder might have been than that perceptions of disorder may act as a multiplier in the process of negative coding that serves as the motor for the deterioration of individual neighborhoods within the urban housing market (Skogan 1990). As noted above, a consistent, independent, correlate of participation in individual and community crime prevention measures is home ownership. On the basis of rational calculation alone, housing tenure-and the relative market value that different tenures imply - will affect the willingness of individuals to participate in crime prevention programs, as well as the type of concern and timescale they bring with them to such programs (Field and Hope 1990). Moreover, the option of community involvement has to contend with the alternative choice of "exit" (Skogan 1988), if that can be exercised. Thus, to stabilize neighborhoods where some kind of market choice of residence operates, city government - or other institutional actors with a stake in particular localities (Taub, Taylor, and Dunham 
1984) - may need to intervene to preserve the exchange value of the neighborhood (Logan and Molotch 1987). ${ }^{2}$

While renters have little stake, other than sentiment, in their dwellings, the owners of their properties clearly do, and it might be that property owners can be encouraged to invest in neighborhood crime prevention as a way of maintaining the value of their properties. Unfortunately, it may be that the economics of low-income rental in the urban market militate against maintenance and upkeep in favor of maximizing rental income-and against investing in neighborhood improvements (Logan and Molotch 1987). However, the public owners of social housing have a nonmarket interest in the long-term value of the neighborhoods in which their housing is located and have an incentive in neighborhood improvement that might include crime prevention activity. Thus if public authorities invest in housing, their tenants gain some of the benefit and thus their own incentive to participate-a principle underlying housing interventions such as the Priority Estates Project (Glennerster and Turner 1993). However, whether public housing tenants actually choose to forgo their option of exit depends presumably on whether the improvements are sufficient to outweigh the perceived benefits of transferring to somewhere even better, including out of the public sector, especially if they are being given incentives to make such a move (see Forrest and Murie 1988).

Trends in public housing in Britain over the past three decades tend to illustrate these processes. Long-term research in Sheffield demonstrates the central importance of housing markets as the determinants of community crime careers, particularly those that allocate tenants to public housing estates (projects) (Bottoms and Wiles 1986; Bottoms, Mawby, and Xanthos 1989; Bottoms, Claytor, and Wiles 1992). Since the 1960s, housing tenure in Britain has polarized between owneroccupation and public rental (Wilmott and Murie 1988), with the virtual disappearance of the private rental sector (Bottoms and Wiles 1986). The expansion of public housing culminated in the early 1970s with the completion of the mass public housing estates; shortly thereafter, the problem of the "difficult-to-let" estate began to emerge.

\footnotetext{
${ }^{2}$ As Bottoms and Wiles (1986) suggest, most "democratic" systems of housing market operate with some degree of resident choice. Typical public housing allocation systems operate on some ranking of needs for prospective tenants that can be bargained against housing availability and some set of criteria whereby tenants can transfer to another dwelling. The modes of exchange built into such systems constitute a form of market, albeit imperfect.
} 
1. Strategy. The issue, therefore, is whether the spiral of urban deterioration-fueled by the stigma of negative neighborhood coding and residents' use of their option of exit-can be forestalled or halted by efforts to preserve or maintain community order. Two issues emerge. First, do communities require external support in maintaining order? While the expectation of the community defense paradigm was that communities would maintain their own social order, the problems of organizing defensive groups in high-crime neighborhoods lead to the question whether the citizens of high-crime communities ought to receive more support and resources for the preservation of order from the wider community. In other words, does the effective operation of the horizontal dimension of orderly communal relations need to be supported by greater resources for control distributed via the vertical dimension of power? Second, if high crime levels are the end product of a sequence of community deterioration, stimulated by low-level disorders, then would a preventive approach be better directed at reducing disorder rather than targeting serious crime?

2. Implementation. The maintenance of public order may require the reintroduction of low-level "functional surveillance" and environmental care. In the Netherlands, the introduction of "social caretakers" onto selected public housing estates-who place more emphasis on patrolling and surveillance in addition to cleaning and maintenancebrought about a decline in nuisance, disorder, and crime in semipublic areas of estates, particularly where there was also a high density of social caretakers to residents (reducing the anonymity of local offenders), combined with measures to restrict access to buildings (Hesseling 1992). Similar effects are claimed for receptionists and "concierges" in public housing blocks in Britain (National Association for the Care and Resettlement of Offenders 1989; Safe Neighbourhoods Unit 1993b). Improved caretaking and maintenance services were also accompanied by reductions in environmental nuisance and disorder in the PEP experiment, described above (Foster and Hope 1993; Glennerster and Turner 1993).

Order maintenance is also seen as a central aim of community and "problem-oriented". policing initiatives (Moore 1992). Community policing measures in Houston seem to have reduced residents' perceptions of disorder and crime and to have increased their satisfaction with their residential environment (Skogan 1990). In particular, it would seem that when police officers concentrate effort on small-scale locales-for example, individual streets or apartment blocks—and adopt a preven- 
tive, collaborative approach with local residents and officials from other agencies, they may well be able to bring the level of disorder under control, even when it is associated with drug sales (Hope 1994). In these examples it appears that disorder can be controlled by restoring order at street level through the efforts of officials who have taken responsibility for small patches of urban space. In this respect, their efforts may have supplemented or restored the "natural" street order celebrated by Jacobs (1962) but that no longer seems to exist in many urban spaces.

3. Evaluation. Nevertheless, there is little evidence currently that the control of disorder at the micro level leads to a reduction in serious crime, despite its effect on residents' perceptions of community safety and satisfaction. Moreover, difficulties emerge with regard to the source of disorder itself. First, the PEP experiment found that although improved maintenance, caretaking, and localized management seemed to reduce both perceived (Foster and Hope 1993) and actual (Glennerster and Turner 1993) levels of "environmental" disorder, such as graffiti, litter, damage, broken lighting, and wrecked vehicles, residents' perceptions of the seriousness of person-related disorder, such as disturbances from youths, noisy parties and neighbors, people mending vehicles in the street, insulting behavior in public, and public drinking and drug use, increased during the experiment (Foster and Hope 1993). ${ }^{3}$ While few might object to cleaning up the environment and removing graffiti, there are issues both of doubtful legality and morality in applying a "clean-up" model to disorderly people, who may indeed be community residents. For example, aggressive police crackdowns on street disorder in Newark, New Jersey, seem to have bordered on the infringement of civil liberties without noticeable effect on residents' levels of fear (Skogan 1990).

Such doubts surround initiatives such as Operation Clean Sweep operated by the Chicago Police Department and Chicago Housing Authority (CHA), targeted on CHA-managed public housing blocks. The operation involves "ousting trespassers, inspecting all [dwelling] units, securing lobbies, installing security guards, and giving residents photo identity cards" that must be displayed to the guards on entering the building (Webster and Connors 1992, p. 2). Although such initiatives may bring much needed relief from the terrorism of violence suffered

\footnotetext{
${ }^{3}$ It is not clear whether this collective change of perception signifies a displacement of anxiety-or shift in tolerance-toward those disorders that remain or an actual increase in such disorders as a consequence of the changed social mix.
} 
by residents (see Kotlowitz 1991), they may also risk turning those residents who are perceived to be the cause of disorder into "something like internal outsiders-unruly kids, marginal people - and the task is to get them off the streets and out of the picture" (Currie 1988, p. 281). Finally, periodic outbreaks of residential vigilantism and public discussion of private security patrols all point to the need for both further research and political debate into the broader question of community justice, which has so far been underresearched (Broadbent 1993).

The second difficulty with the order-preservation approach lies in the possibility that, despite its potential draconian scope, such measures may still not be sufficient to withstand the wider pressures affecting the stigmatization of neighborhoods within the operation of urban housing markets (Logan and Molotch 1987). Neither the English PEP nor the Dutch social caretaker experiments cited above managed to halt the high rate of tenant turnover on the estates studied. And if, as Taub, Taylor, and Dunham's (1984) research suggests, residents' perceptions of environmental conditions are mediated by the exchange values of the housing market, then perhaps efforts should be directed as much, if not more, toward neighborhood economic investment than to the control of overt disorder.

\section{B. Protecting the Vulnerable}

Unlike the U.S. National Crime Survey, the sampling structure and geodemographic coding of the British Crime Survey (BCS) can support contextual and areal analyses of victimization (see Sampson and Groves 1989). Combined with information on multiple victimization also provided by the BCS, such facilities have encouraged a new focus on the prevention of victimization within the community. Estimates from the BCS suggested that the residents of three types of social area, common in inner cities, with high prevalence rates for victimization-who comprised only 12 percent of the population-suffered particularly disproportionately from predatory crimes. This included 37 percent of all burglaries, 33 percent of all robberies and thefts from the person, and 23 percent of all thefts from motor vehicles that occurred in England and Wales (Hope and Hough 1988). Moreover, BCS analysis also suggests that the concentration of crime in such areas is due less to the prevalence of crime (that there were proportionately more victims among their resident populations) than to the vulnerability of victims living there (that each victim is likely to experience a much greater 
number of victimizations than would a victim in a lower-crime neighborhood) (Trickett et al. 1992). In other words, high-crime areas have many more multiple victims-who, of course, each contribute disproportionately to their community's higher crime rate.

1. Strategy. A strategy for reducing harm in high-crime communities by targeting effort on the disproportionate number of repeat or multiple victims who live there has been outlined recently by Farrell and Pease (1993; see also Farrell, in this volume). From a community prevention perspective, the approach may be considered to have a number of advantages. First, it may prove to be a cost-efficient strategy of allocating scarce preventive resources among community members, since prior victimization would seem predictive of future victimization. ${ }^{4}$ Second, since repeat victimization is highest in the most crimeridden areas, the approach automatically targets such areas for attention and may have a significant impact on aggregate crime levels, if successful. And third, the rate of repetition in a community offers a sensitive and realistic scheduling of the "dosage" of preventive effort, "drip feeding" crime prevention into communities. By definition, then, the approach should automatically target the most vulnerable in the highest-crime areas.

2. Implementation. A considerable range of initiatives targeted on multiple victims was brought to bear during the Burglary Prevention Project implemented on the Kirkholt Estate in Rochdale, Englandan economically disadvantaged public housing estate of some 2,280 dwellings (Forrester et al. 1990; Pease 1992). These included upgrading the security of recently victimized dwellings, property marking, and removal of prepayment utilities meters (Forrester, Chatterton, and Pease 1988). The local Probation Service organized group work and community service programs for local offenders; this was accompanied by the establishment of a credit union for residents and a school-based program for local youth (Forrester et al. 1990). A particular innovation-in the light of the discussion of the community defense paradigm - was to establish 'cocoon' watching groups-small groups consisting only of the immediate neighbors of recently victimized households. Considerable success in organizing cocoon groups was re-

\footnotetext{
${ }^{4}$ This assumption derives from the often-noted, though little understood, observation that the frequency distribution of victimization, apparently howsoever measured, does not fit the assumptions of the Poisson process and from the empirical observation of the relatively short time interval between victimization events experienced by multiple victims (see Farrell, in this volume).
} 
ported (Forrester et al. 1990), with seventy-five groups established on the estate within a seven-month period (Forrester, Chatterton, and Pease 1988). Cocoon groups may be successful, presumably, because they capitalize on personal vulnerability-dramatized by the recent victimization of a neighbor-and because the smallness of the group reinforces preexisting neighbor relations and increases the social pressure to participate, thus obviating the free-rider problem noted above (Hope 1988b).

3. Evaluation. The Kirkholt Burglary Prevention Project appears to have brought about a 75 percent reduction in the incidence rate of burglary on the estate over a three-year period, including an immediate and sustained reduction, to negligible proportions, of the rate of repeat victimization (Forrester, Chatterton, and Pease 1988). Nevertheless, as with many community prevention projects, it remains unclear what mechanisms were involved in achieving the reduction and, particularly, what might have been the precise contribution of the specific strategy of preventing repeat victimization. For instance, a wide range of other community development approaches and estate improvements-similar to those described in Section I-were also implemented on the Kirkholt estate before and during the Burglary Prevention Project (Safe Neighbourhoods Unit 1993b). Given the range, mix, and contemporaneity of these initiatives, it remains unclear to what extent the specific measures to prevent repeat victimization depended both for their implementation and for their impact on more general changes in community control that these other measures might have brought about. It is possible, for instance, that burglary could have been reduced on Kirkholt through the cumulative effect of all or many of the improvement measures, which together may have empowered residents, and more effectively integrated them with local institutions, in which the specific victim-prevention measures may have played an important though not necessarily unique or decisive part. For example, a combination of consistently responsive estate management, improved building security, and population stabilization on the London control estate in the PEP Experiment (see n. 1) also seems to have brought about an increase in residential surveillance and comparable, dramatic reductions (79 percent) in the burglary incidence rate over a similar three-year period (Hope and Foster 1992).

Unfortunately, weaknesses in the evaluative design of the Kirkholt Experiment obscure investigation of the mechanisms or sets of causal processes by which the reduction of repeat victimization and in the 
aggregate crime rate might have been brought about (Tilley 1993). ${ }^{5}$ The observed concentration of repeat victimization in high-crime communities, and the possibility that high crime rates are due less to there being more victims than to there being more victimization (Trickett et al. 1992), constitutes one of the most intriguing - and potentially most important-criminological insights of the decade. Nonetheless, our current lack of knowledge about why this should be so hinders the design of community-oriented preventive measures based on it.

The problem turns, fundamentally, on the explanation of the concentration of victimization in high-crime communities. It might be argued that community differences in crime rates are due primarily to differences in the residential concentration of repeat victims-in other words, that there may be no collective community effect as such, merely the aggregation of vulnerable victims, on whom preventive resources should be targeted for maximum effect (Pease 1993). In this sense, area differences have no intrinsic significance other than as an effective predictor of where most victimization is likely to be located. Having located such areas, preventive action should be directed to halting the revictimization of individuals - or that occurring at crime hot spots within such areas. Measures would be individualized, aimed at reducing the likelihood of repetition by, for instance, altering the situational circumstances that occurred at the previous incident (Farrell and Pease 1993; see also Clarke, in this volume). ${ }^{6}$ Even so, it is at present unclear whether "multiple" victims can be distinguished a priori from victims generally and, particularly, whether their "excess risk" is portable. If it were possible to find unique features that characterized potential repeat victims in advance, then it might also be possible to implement ways of affecting their residential concentration, in effect equalizing differences in areal crime rates (see Barr and Pease 1990). If, conversely, it turns out that repetition cannot be predicted prior to onset - and that the risk of repetition is situation dependent-then the strategy should be to focus on preventing repetition rather than onset (Farrell and Pease 1993).

\footnotetext{
${ }^{5}$ The general problem of evaluation in crime prevention-applicable equally to community prevention efforts-is discussed more fully in Ekblom and Pease (in this volume).

6 The situational "bias" of this line of reasoning is reinforced by the observed short time interval of revictimization (see Farrell, in this volume), calling for a "quick and transient" response to the limited heightened risk period of revictimization (Farrell and Pease 1993).
} 
However, to the contrary, it may be that the concentration of multiple victims in high-crime areas is not a product solely of individual vulnerability. Recently, Farrell (in this volume) has outlined a simple, formal model that suggests that if, according to routine activity theory, the "probability that a violation will occur at any specific time and place might be taken as a function of the convergence of likely offenders and suitable targets in the absence of capable guardians" (Cohen and Felson 1979, p. 590, emphasis added), then the excessive concentration of victimization in high-crime areas could be accounted for as a multiplicative-though not additive-effect of an increase (or higher level) of all three routine activity elements, but not of an increase in only one or two of the elements. Thus a greater concentration of vulnerable individuals would not necessarily lead to a concentration of victimization unless it occurred in circumstances where there was also a concentration of motivated offenders and an absence of guardianship. Consequently, in this interpretation, altering the vulnerability of victims alone might not reduce the concentration of victimization unless measures were taken simultaneously to reduce the motivation of offenders and to increase the capability of guardianship. Arguably, it may have been the multiplicity of interventions on the Kirkholt Estate (Forrester et al. 1990) that achieved this effect rather than those specifically targeted at repeat victims, even if the chief beneficiaries were those who might otherwise have been multiply victimized.

Nevertheless, the insight-that high-crime areas are so because of their rate of victimization rather than their rate of victims-is a novel one and opens up a range of research questions whose resolution might produce a radical reconceptualization of the theory of community crime prevention. In particular, the possibility that multiple victims are indicative of the routinized copresence of "criminogenic others" in space and time suggests ways in which recent social theorizing might enhance the development of routine activity theory (Bottoms and Wiles 1992) - though much more theoretical and empirical work needs to be done. A particular concern is to establish what it is that marks out some residents in a community as candidates for the repeated attention of offenders-presumably many of whom are coresidents. The form that prevention takes eventually will depend on whether the answer lies in the excessive vulnerability of some victims or in the motivation of those offenders who-in the perhaps apposite language of the school playground-repeatedly pick on them. 


\section{Conclusion}

What has been learned from over sixty years of effort? To return to a point made in the introduction to this essay, if community crime prevention was a cumulative science, it might be possible to gauge the answer in terms of progress made toward the utopia of crime-free communities. However, it should by now be apparent that the various community prevention paradigms of the past have arisen as responses to contemporary perceptions of the problem of crime in urban areas. To the extent that the urban crime problem is perceived to have changed, so the lessons of the past become less relevant for the future. Nevertheless, two general issues seem to have persisted. The first concerns the possibility of informal social control among residents of highcrime communities - that is, the significance of the horizontal dimension of community relations. The second concerns the dependence of local social order on the pressures and structures of the wider societythat is, the importance of the vertical dimension of community integration.

\section{A. Social Control in Higb-Crime Communities}

If there has been any continuity in this field, it is the communitarianism inherent in the legacy of Shaw and McKay-the belief that the solution to neighborhood crime problems can be achieved primarily through the self-help efforts of residents. In the community-organizing approach this involved the building of indigenous local institutions to serve as agencies of socialization for local youth. The tenant involvement approach stressed the creation of representative self-management of the residential environment. The strategy of resource capture saw the political mobilization of communities as a strategy for gaining more resources. More recently, the community defense paradigm has focused on organizing collective self-defense against predators. Efforts to preserve order have been justified to preserve informal relations within communities, while the adoption of "cocoon" watch groups in the prevention of repeat victimization seeks to build on neighborly protective self-interest. The common theme in all these efforts has been that residents should organize collectively to create or support institutions for dealing with the crime problems that beset their residential space. Braithwaite (1989, p. 85) defines a "communitarian society" as combining a "dense network of individual interdependencies with strong cultural commitments to mutuality of obligation." Interdependence and mutual obligation together provide the resource for social control; not 
only are members of such a community likely to be subject to shame or exclusion if they individually transgress (Braithwaite 1989) but also each individual feels confident to enlist the support of others to act on deviants and maintain the norms of the community (Kornhauser 1978). Nevertheless, it has proven difficult to initiate community organization against crime in high-crime areas and difficult to sustain involvement in low-crime areas. Does this mean that "communitarianism" does not work?

Part of the problem may be that the communitarian approach sets up communal solidarity as the sole mode of social control for residential areas. Yet, social order in affluent suburban communities may be maintained by its opposite, a strategy of social avoidance, or moral minimalism (Baumgartner 1988). Weak ties between residents in suburban areas, and high residential mobility, can mean that conflicts between residents are transient; residents possess little information about each other and so cannot exploit such knowledge, for better or worse; residents have multiple activity groups that divert their attention away from conflict; and residents lack the support from neighbors for vengeance or intimidation (Baumgartner 1988). Moral minimalism therefore works because the sources and opportunities for conflict among residents are avoided-privacy rather than communalism would seem to preserve the order of the suburb. Is moral minimalism a better strategy for social control?

Perhaps neither undiluted communitarianism nor moral minimalism is appropriate given one of the key defining features of high-crime communities - that residents are frequently victimized by coresidents. The ecological correlation between offender and offense rates (Bottoms and Wiles 1986) suggests that, at the extremes at least, highly victimized neighborhoods are also likely to have high rates of offenders among their residents, many of whom do most of their offending in their home locality (Brantingham and Brantingham 1984). In any event, the British Crime Survey found that the majority of residents living in the poorest, most victimized council housing areas believed that most offenders were local people (Hope 1986b). Nevertheless, the approaches reviewed above differ in the way they have considered the relationship between putative victimized and offending groups; particularly whether each was thought to be part of the community. The approaches described in Section I-community organizing, tenant involvement, resource capture-remained silent as to the identity and location of the victim group but saw offenders-usually adoles- 
cents-as part of the community. In contrast, the approaches described in Sections II and III-community defense, preserving order, protecting the vulnerable-saw offenders implicitly as outsiders, while community members were seen as the potential victims from primarily external predation.

The avoidance strategy of the suburbs would seem to operate mostly against strangers. Suburbanites may be extremely averse to any contact with strangers; they may readily invoke police or private security to deal with "suspicious persons" (Baumgartner 1988); their environments may be difficult for strangers to penetrate, physically and symbolically (Greenberg, Rohe, and Williams 1985); and their emphasis on privacy provides outsiders with few opportunities to gain access to their persons or property (Baumgartner 1988). Yet, when potential predators live in close proximity - and "belong" to the locality - potential victims may find simple avoidance hard. Understandably, they may be wary about trusting their fellow residents, who might turn out to be predatory, and reluctant to embrace their potential victimizers in reintegrative activities, desirable though that may be for a wider social order (Braithwaite 1989).

Surprisingly, despite its intrinsic interest and significance for local social order, there has been little systematic research on the nature of intracommunal offending and on how residents adjust their lives to it. It is possible, however, that social networks witbin communities might mediate intracommunal offending (Krohn 1986). As with the communitarian ideal, internal networks may play an important role in the prevention of local youth crime. Sampson and Groves (1989), for instance, have presented some empirical evidence from the British Crime Survey-consistent with Kasarda and Janowitz's (1974) "systemic model" of community organization (see also Bursik and Grasmick 1993) - suggesting that the extent of community friendship ties is inversely related to levels of victimization. Sampson (1985) also suggests that a high proportion of divorced or working single mothers in a neighborhood reduces informal social control because the likelihood of significant adults noticing and acting on the delinquency of neighborhood youth is reduced (Sampson 1987a). Such control is not so much a matter of the supervision of individual delinquents by their own parents as of the presence of a network of families that collectively sustains an infrastructure of supervision and normative reinforcement. Thus, Sampson and Groves (1989) report that community rates of family disruption are positively related to the prevalence of disorderly 
teenage groups. A community's network of parental support may be its "social capital" - a resource available to individual families for safeguarding their own children's conduct, and an important, informal mechanism for socialization (Sampson 1992).

An unfortunate consequence of the general failure of Shaw and McKay to define "disorganization" (Bursik 1988) has been to foster an image of high-crime neighborhoods as an atomized collection of isolated households. Yet, ethnographic research in slum neighborhoods has often found strong primary links between residents (see Whyte 1955; Suttles 1968; Merry 1981; Horowitz 1983) and has repeatedly failed to find evidence of widespread interpersonal isolation (Freudenberg 1986). The reciprocity of acquaintanceship, particularly among neighbors, would seem to be a powerful incentive for all but those living the most transitory lives, even if the qualitative content of neighborly relations is fairly minimal (Bulmer 1986). Social networks in a neighborhood are also an important means of communicating information about crime and mediating its effects on perceptions of community safety (Skogan and Maxfield 1981). Some residents of high-crime neighborhoods may have been able to practice a hybrid form of ordermaintenance-a sort of group minimalism - by creating a segmented social order in their neighborhoods (Suttles 1968).

Ethnographic research shows how residents in high-crime areas adopt interpersonal strategies and affiliations, based mostly on primary relationships, to ensure their own safety, well-being, and prospects (Suttles 1968; Kornhauser 1978; Merry 1981; Anderson 1990; Furstenberg 1993). Likewise, community studies on British council estates have shown a fragmentation on cultural lines, especially the selfimposed insularity of the "respectable" working class (Reynolds 1986; Bottoms, Mawby, and Xanthos 1989; Foster and Hope 1993). The essence of such group formation is that it serves to define who can be trusted and who may be dangerous (Merry 1981), acting as a buffer to insulate individuals from potential predators and malign influences, especially among those living close by. Yet, we know very little about the extent to which offending and victimization within communities is mediated by social networks among residents. For instance, the relatively flat gradient in victim prevalence rates between low- and highcrime areas (discussed in Sec. III) suggests, possibly, that the victim population in any community may have finite limits. Yet, it is not clear whether the offending population is coterminous with it, while other groups remain virtually insulated from local crime. 
It is possible that there may coexist subpopulations, even within high-crime communities, some of whom are heavily involved with crime-as victims or offenders-while others remain relatively immune. For example, the greater likelihood of victimization from property crime of households headed by female single parents (Smith and Jarjoura 1989) may be due to their greater likelihood of being victimized by people personally associated with them (Maxfield 1987). Similarly, changes during the PEP experiment on the Hull estate (described in Sec. I above) served, simultaneously, to widen delinquent and adult offending networks, to reduce victimization in some areas of the estate while concentrating it in other areas, and on particular social groups, while residents in other parts-comprising about 21 percent of households-retained low levels of victimization throughout the experiment (Foster and Hope 1993). This fragmented pattern of responses to change is complex, particularly calling into question the image of the community as a unitary phenomenon that will change uniformly in response to specific policy inputs. Much more work is needed to explore how intracommunal networks mediate the effects of external policy changes on patterns of intracommunal offending.

Though the impulse to ensure personal safety may lead to the formation of close-knit but fragmentary social networks, this does not mean that such a solution may be particularly effective in promoting safety or reducing crime within the community as a whole. Even in situations where the mosaic of networks appears relatively stable (Suttles 1968), segmentation may render the community incapable of self-organization. Regardless of whether individual groups-or even individual families (see Furstenberg 1993)—are "organized," they are unlikely to expand to recruit others or to form bridges with other groups both because they are predicated on mistrust and because their introverted nature provides few opportunities to form ties with members of other groups. Without such linkages, secondary organizations are unlikely to be extended across a community (Granovetter 1973). As with cocoon watch groups (Sec. III above), physical propinquity (Suttles 1972) and the reciprocity of neighborliness (Bulmer 1986) may provide the occasion for network formation, yet external impetus would appear to be needed in order to federate such groups into a broader community organization.

Why do victims of internal offending have neither formal nor informal redress against predation from those with whom they live? Why is the repetitive victimization of residents most common in those areas 
that are likely to have higher proportions of internal offenders (Sec. III above)? Again, the lack of research on intracommunal offending offers little help in answering what are surely key issues in the development of social control in high-crime communities. Two directions offer themselves for research and policy development, each reflecting the distinction between communitarianism and moral minimalism. One direction would be to continue further with the communitarian ideal of creating an institutional structure that overcomes victims' desires to exclude or avoid internal offenders, and offenders' lack of scruple about victimizing their coresidents. In order to do this, however, it would be necessary to create conditions of interdependence and mutuality among community members (Braithwaite 1989). Past efforts provide little comfort as to how and whether this can be achieved.

The other direction would be to pursue the line of inquiry suggested by Black $(1983,1984)$ where much crime is seen as the redress of grievance, real or imagined, for which alternative means are unavailable-including lack of access to the agencies of both criminal and civil law. Since the preservation of privacy in the strategy of moral minimalism is underpinned by easy and swift access to the protection of law (Baumgartner 1988), an approach that made legal and other forms of conflict and grievance resolution available to high-crime communities might divert those interactions between community members that might otherwise lead to criminal actions. That policy thinking, as far as it can be discerned, has failed to address either possibility in respect to high-crime communities calls for considerable rethinking of the purpose and possibility of community crime prevention.

In sum, another part of the legacy of Shaw and McKay, which may no longer be helpful for community crime prevention, is the failure to recognize other modalities of social order than the polarity between communitarianism and disorganization. Nevertheless, neither have the political or moral implications of seeking to implant strategies of segmentation or moral minimalism into high-crime communities been considered. The dilemma-that neither research nor policy has yet resolved-is whether to enforce a segmented order-with the likely consequence of social exclusion of the deviant or troublesome and a reification of their deviance (Cohen 1985)-or to strive for the integration of deviants into their communities (see Braithwaite 1989) —even if, in the short run at least, this might be more to the benefit of the deviant than to those who are subject to their deviance. 


\section{B. The Political Economy of Prevention}

Throughout this essay, the operation of urban markets, primarily in housing and employment, has been identified as a crucial context both for the development of community crime problems and for community-based responses. The community-organizing approach of the Chicago Area Project was framed to counter the social imperfections of the dynamic growth of the urban market (Shaw and McKay 1969), while more recent studies of Chicago (Bursik and Webb 1982; Taub, Taylor, and Dunham 1984; Bursik 1986), Los Angeles (Schuerman and Kobrin 1986), and Sheffield (Bottoms, Claytor, and Wiles 1992) have each demonstrated how community crime rates, and resident responses, are shaped by supply-and-demand factors of land use and housing in the city. A general sequence would appear to be that changes occurring in local urban markets, often stimulated by private or public corporate investment decisions (Taub, Taylor, and Dunham 1984; Logan and Molotch 1987), alter prevailing land uses (Schuerman and Kobrin 1986) or residential preferences (Taub, Taylor, and Dunham 1984), which then engender changes in population composition (Bottoms and Wiles 1986; Bursik 1986), which consequently changes the internal culture of residential areas (Bottoms, Mawby, and Xanthos 1989), perhaps often despite community-based effort (Foster and Hope 1993). Change in the dynamics of the urban market, in which individual communities are located; thus has a major impact on their levels of crime and disorder, mediated by the employment and housing opportunities available to both current and prospective residents.

Partly because of the inheritance of communitarianism, prevention strategies have focused on the promotion of the "use values" of residential areas-that is, the benefits to residents that flow from neighborly reciprocity, informal support networks, a sense of identity, and, importantly, security and trust (Logan and Molotch 1987). Such efforts are often threatened, however, by the dynamics of a neighborhood's "exchange value"-how properties (and by extension the community itself) are valued by prospective residents, landlords, and investors (Logan and Molotch 1987). One enduring part of the legacy of Shaw and McKay is the finding that the urban market affects the internal social order of communities through its impact on the rate and type of residential mobility (Kornhauser 1978; Sampson and Groves 1989; Bursik and Grasmick 1993). It is possible then that intervention and investment in the urban market to develop the exchange value of particular residential areas would bring about a reduction in crime. How- 
ever, before the implementation of ways of controlling or mediating the impact of mobility, it remains necessary, among other things, to account for Taylor and Covington's (1988) seemingly anomalous finding that gentrifying as well as pauperizing neighborhoods suffer increasing violence during the process of change. This points again to the problem of intracommunal offending. For example, it would be necessary to ascertain whether newcomers were being victimized by current residents, current residents were increasing their victimization of one another as social controls broke down following the departure of stable community members, or whether newcomers were importing their own violence with them. Each situation would have different consequences for social control, but these alternative possibilities also illustrate the necessity of understanding how the internal dynamics of individual communities (the horizontal dimension) are related to their position in the wider market (the vertical dimension).

Research studies along the lines of those by Taub, Taylor, and Dunham (1984) and Bottoms and Wiles (1986) would help in understanding how to influence the linkage between exchange and use values so as to reduce crime rates (Hope 1986a). Ironically, much of the organized activity of affluent suburban communities is concerned, in one way or another, with the promotion of exchange values (Logan and Molotch 1987). "Preservationist" community groups (Skogan 1988) are likely to adopt community defense models (Sec. II above). Homeowners, those particularly sensitized to exchange values (Taub, Taylor, and Dunham 1984), have been shown to be more likely to participate in community prevention efforts. The PEP intervention is in part intended to address the problem of difficult-to-let estates. Factors affecting exchange values therefore would seem as important for community crime prevention as those that might affect use values.. An emphasis on use values tends to direct attention to the intrinsic qualities of specific neighborhoods, while a concern for exchange values directs attention equally to the position that a neighborhood has, within the urban system (Bursik and Grasmick 1993).

While the nature of recent transformations of the advanced economies is complex and continuing (see Harvey 1989; Lash and Urry 1994), two key ecological processes occurring within urban systems are affecting the exchange values of communities. The first is counterurbanization, the general movement of jobs and populations out of the older cities into more rural areas or into metropolitan regions of considerable size and disparity (Champion 1989). The second is the concentra- 
tion of poverty in the older urban areas-the increasing tendency for the poorest segment of the population to live in communities of general poverty and isolation from wider social and economic institutions (Wilson 1991a, 1991b). Both processes have differing consequences for community crime prevention.

1. Counterurbanization. The conditions of modernity would appear to have "lifted out" social relations from the close proximity of the residential environment (Giddens 1990). The spatial mobility provided by automobiles-as both cause and consequence of counterurbanization-means that the activity space for counterurban residents no longer necessarily spans the area within walking distance from home but a wide and diverse region. In particular, this provides potential offenders with the capacity to evade the control of their families and neighbors and to commit crimes far afield (Felson 1994). Moreover, because location of residence is not tied necessarily to location of employment, the exchange value dynamics of the urban market may be creating a highly socially and economically segregated set of communities within a new counterurban suburbia (Logan and Molotch 1987). None of these processes would suggest that communitarian strategies would be successful in maintaining order in the new counterurban environments; though nor, it seems, are they necessary. Since temporary access to such areas is dependent on spatial mobility (Felson 1987), and permanent access dependent on earnings and income, they may be becoming less accessible to low-income offenders who lack the means of spatial and social mobility. The reconfiguration of counterurbia may be producing a sociospatial exclusion of the "dangerous poor" (Davis 1990; see Lash and Urry 1994).

Braithwaite (1993) argues that individuals are provided in modern societies with a wide range of reference groups and communities of interest, based mainly on occupation, who could as effectively provide shame and reintegration as communal villages. Thus the residential area no longer needs to provide controls based on interdependence and mutuality. If, therefore, the civic and moral space of the suburb becomes hollowed out, then such controls as may be needed may be found simply in the strategy of moral minimalism. Paradoxically, if social control in the counterurban suburb rests on the exclusion of strangers through strategies of privacy and avoidance, then the community defense model might indeed promote social control there, provided less emphasis was given to communitarianism and more to establishing effective communication between individual householders and 
the police (or private security), who would then-with a commensurate allocation of resources-be able to provide more efficient guardianship of the residential space. The way in which Neighbourhood Watch has often been described in British police circles as the "eyes and ears of the police" would suggest that this point is well taken intuitively (see McConville and Shepherd 1992). Finally, such efforts in the counterurban community would probably need to be underpinned by concerted action to maintain exchange values-and to attract inward investment-in order to insure against the threat of competition, declining exchange values and, therefore, of destabilizing mobility (Davis 1990). Of course, the implications for the wider public good of this evolving social order of counterurbia have as yet to be scrutinized in political debate.

2. Poverty Concentration. Counterurbanization, however, may be selective, creating a spatial mismatch between the movement of employment out of the inner city and the spatial and skills immobility of inner-city residents (Wilson 1987). Analysis of the 1984 British Crime Survey suggests that three characteristics of social areas, derived from the 1981 United Kingdom Census, stand out particularly as distinguishing high crime (incidence) rate areas: the male unemployment rate; the proportion of the population who were children aged five to fifteen years; and, importantly, a composite variable including high proportions of young adults (aged sixteen to twenty-four years), singleadult households (with and without dependent children), and households not living in self-contained accommodation (Osborn, Trickett, and Elder 1992). In parallel with American research, the high-crime area is defined increasingly by the linkage between economic conditions and community social structure. For instance, a high rate of male joblessness appears to influence residential community crime rates primarily through its effect on the disruption of families and on family formation among residents, indexed particularly by the rate of female-headed households with children (Sampson 1985; Messner and Sampson 1991). Moreover, the British Crime Survey suggests that in England and Wales both property crime and, to a lesser extent, personal crime have become more inequitably distributed between areas between 1982 and 1988, largely due to an increasing inequality in the rate of victimization rather than in the rate of victims (Trickett, Ellingworth, and Pease 1992).

In broad terms, then, high-crime communities in both Britain and America now seem to be characterized increasingly by concentrations 
of jobless young men and by single-adult households, often headed by women and often with dependent children. If the dynamics of postindustrial societies are redistributing and concentrating economic inequality among residential areas-particularly affecting the spatial concentration of the young poor (see Foster and Hope 1993) - then it may be that such community resource deprivation is being accompanied (in Britain) by an increasing spatial and interpersonal inequality of victimization and (in the United States) by high rates of violence and homicide (Land, McCall, and Cohen 1990; Messner and Golden 1992). In other words, the increasing inequality of victimization between communities may be characterized in both societies by an increase in the frequency and severity of harm, arguably as an expression of an increasing intensity of intracommunal offending.

Past approaches, particularly based on voluntary communitarianism, will not be sufficient to address these problems. If violence results from youth's detachment from institutions providing socialization and economic opportunity (Kornhauser 1978), then Cloward and Ohlin's (1960) analysis of slum youth's delinquency finds some contemporary support in recent American ethnographic research-which suggests that inner-city black youth are more likely to turn to street robbery and drug dealing in their own neighborhoods as the only source of supplemental income in their middle to late teens, given a lack of access to job markets and networks and the social and physical isolation of their communities (Sullivan 1989; Anderson 1990). The experience of the federal Violent Juvenile Offender Research and Development Program (1981-86) in high-crime neighborhoods of six American cities suggested that the real problem in these neighborhoods was not so much an absence of potential for community cohesion and leadership as that they were underserved by the social service network and were economically worse-off than other areas (Fagan 1987). What implications do these findings have for the promotion of social order?

If moral minimalism is underscored by residents' access to resources of law and to employment-based communities of interest, then the intracommunal offending, underpolicing, and chronic joblessness of areas of concentrated poverty deny residents access to these resources, and of recourse to moral minimalism. Aside from material need, longterm unemployment excludes people from the wider society and limits their horizons to the local community. As witnessed during the PEP experiment, the residential concentration of the young poor fostered a "subterranean community" both victimized and victimizing (Foster and 
Hope 1993). Thus the residential concentration of youth poverty seems to be creating communities with concentrations of high-risk offenders-often young, jobless men-and multiple victims-often female heads of households (Genn 1988), linked together in a powerless, victimizing-and-victimized culture of primary relationships (see Campbell 1993).

An appropriate crime prevention strategy might therefore start by addressing the subterranean nexus of youth poverty and crime emerging within areas where crime and poverty are concentrating. Nearly two decades of policy attention to community defense and the preservation of order have diverted attention from the problem of youth crime in high-crime communities (Curtis 1988), a problem that was the primary focus of earlier prevention paradigms but which has received little attention from researchers and policy analysts, even while the intensity of crime and drug problems has increased in urban neighborhoods. Research and policy development, especially in Britain, is needed urgently to recapture the aims of earlier approaches and to recast them in the context of a contemporary urban political economy.

Yet, unlike the earlier efforts, prevention needs to deal with two major features of high-crime communities. First, areas with concentrations of offenders are also those with concentrations of victims that intracommunal relations (the horizontal dimension) may be victimizing. Thus efforts to mobilize resources of support and control for youth must be accompanied by efforts to protect the fearful, vulnerable, and victimized if the destabilization of community is to be arrested. Otherwise, residents will continue to exercise their power of "exit" where they can. But nor should the protection of the vulnerable have the unintended consequence of excluding the deviant-which the counterurban strategy of moral minimalism implies-or of escalating the criminality of offenders.

Second, community crime prevention needs to address the possibility that informal resources for prevention within contemporary highcrime residential communities are being undermined by their increasing economic, social, and political isolation from the rest of society (Wilson 1987). One of the significant legacies of Shaw and McKay's work was to highlight the importance of social institutions in holding communities together and, especially, in socializing the young. Institutions are able to function in this way because they are a two-way conduit between the community and the wider sources of wealth and power (Kornhauser 1978). For Shaw and McKay, the process of urban 
growth had moved faster than the development of social institutions; the task of CAP was thus to intervene to ameliorate the defects of the urban market. Now, the processes of urban decline and global economic change have undermined those fragile institutions that preserved order and fostered citizenship, albeit precariously, in the mid-century working-class community (Clarke 1987). Thus the second direction for future development is to explore the possibility of a new institutional structure of order (Dahrendorf 1985) in residential areas that have seen a concentration of crime. Disintegrating urban communities may need significant social investment in their institutional infrastructure to offset the powerful tendencies of destabilization of poor communities within the urban free-market economy (Logan and Molotch 1987). Unlike in the emerging counterurban social order, the privatized option of moral minimalism will not be sufficient; the spatial horizons of the poor, and their arena of daily life, are still rooted in their residential locality, and localized, community-based solutions are still necessary.

Of course, more research and policy analysis is necessary to develop such a strategy. Whether this happens, however, depends primarily on political will. As this essay has sought to show, community prevention models have arisen as political responses to the imperatives of contemporary urban problems. It remains to be seen whether, and to what degree, governments in the advanced economies of North America and Europe choose to respond to the imperatives of counterurbanization or to those of poverty concentration.

RE FER E N C E S

Anderson, Elijah. 1990. Streetwise: Race, Class and Change in an Urban Community. Chicago: University of Chicago Press.

Barr, R., and K. Pease. 1990. "Crime Placement, Displacement, and Deflection." In Crime and Justice: A Review of Research, vol. 12, edited by M. Tonry and N. Morris. Chicago: University of Chicago Press.

Baumgartner, M. P. 1988. The Moral Order of a Suburb. New York: Oxford University Press.

Bennett, T. 1989a. "The Neighbourhood Watch Experiment." In Coming to Terms with Policing: Perspectives on Policy, edited by R. Morgan and D. J. Smith. London: Routledge. 
. 1989b. "Factors Related to Participation in Neighborhood Watch Schemes." British Journal of Criminology 10:207-18.

- 1990. Evaluating Neigbbourbood Watch. Basingstoke: Gower.

Black, Donald. 1983. "Crime as Social Control." American Sociological Review 48:34-45.

— Problems. Orlando, Fla.: Academic Press.

Bottoms, A. E., A. Claytor, and P. Wiles. 1992. "Housing Markets and Residential Community Crime Careers." In Crime, Policing and Place, edited by D. J. Evans, N. R. Fyfe, and D. T. Herbert. London: Routledge.

Bottoms, A. E., R. I. Mawby, and P. Xanthos. 1989. "A Tale of Two Estates." In Crime and the City: Essays in Memory of Jobn Barron Mays, edited by D. Downes. Basingstoke: Macmillan.

Bottoms, A. E., and P. Wiles. 1986. "Housing Tenure and Residential Community Crime Careers in Britain." In Communities and Crime, edited by A. J. Reiss, Jr., and M. Tonry. Vol. 8 of Crime and Justice: A Review of Research, edited by M. Tonry and N. Morris. Chicago: University of Chicago Press.

- 1988. "Crime and Housing Policy: A Framework for Crime Prevention Analysis." In Communities and Crime Reduction, edited by T. Hope and M. Shaw. London: H.M. Stationery Office.

- 1992. "Explanations of Crime and Place." In Crime, Policing and Place, edited by D. J. Evans, N. R. Fyfe, and D. T. Herbert. London: Routledge.

Braithwaite, J. 1989. Crime, Shame and Reintegration. Cambridge: Cambridge University Press.

—. 1993. "Shame and Modernity." British Journal of Criminology 33:1-18.

Brake, M., and C. Hale. 1992. Public Order and Private Lives. London: Routledge.

Brantingham, P., and P. Brantingham. 1984. Patterns in Crime. New York: Macmillan.

Bright, J. 1991. "Crime Prevention: The British Experience." In The Politics of Crime Control, edited by K. Stenson and D. Cowell. London: Sage.

Bright, J., and G. Petterson. 1984. The Safe Neighbourboods Unit Report. London: National Association for the Care and Resettlement of Offenders.

Broadbent, P. 1993. "Policing-Private or Public: Conference Proceedings." Manchester: Manchester Metropolitan University Law School.

Bulmer, M. 1986. Neigbbors: The Work of Pbilip Abrams. Cambridge: Cambridge University Press.

Burbidge, M. 1984. "British Public Housing and Crime: A Review." In Coping with Burglary, edited by R. Clarke and T. Hope. Boston: Kluwer-Nijhoff.

Bursik, R. J. 1986. "Ecological Stability and the Dynamics of Delinquency." In Communities and Crime, edited by A. J. Reiss, Jr., and M. Tonry. Vol. 8 of Crime and Justice: A Review of Research, edited by M. Tonry and N. Morris. Chicago: University of Chicago Press.

- 1988. "Social Disorganization and Theories of Crime and Delinquency: Problems and Prospects." Criminology 26:519-51.

. 1989. "Political Decision-Making and Ecological Models of Delin- 
quency: Conflict and Consensus." In Theoretical Integration in the Study of Deviance and Crime, edited by S. F. Messner, M. D. Krohn, and A. E. Liska. Albany: State University of New York Press.

Bursik, R. J., and H. G. Grasmick. 1993. Neigbborboods and Crime. New York: Lexington.

Bursik, R. J., and J. Webb. 1982. "Community Change and Patterns of Delinquency." American Journal of Sociology 88:24-42.

Campbell, B. 1993. Goliath: Britain's Dangerous Places. London: Methuen.

Central Office of Information. 1989. Practical Ways to Crack. Crime: The Handbook. 3d ed. London: Central Office of Information.

Champion, A. G., ed. 1989. Counterurbanisation: The Cbanging Pace and Nature of Population Deconcentration. London: Edward Arnold.

Cirel, P., P. Evans, D. McGillis, and D. Weitcomb. 1977. An Exemplary Project: Community Crime Prevention Program, Seattle, Washington. Washington, D.C.: National Institute of Law Enforcement and Criminal Justice.

Clarke, M. J. 1987. "Citizenship, Community and the Management of Crime." British Journal of Criminology 27:384-400.

Clarke, R. V., ed. 1992. Situational Crime Prevention: Successful Case Studies. New York: Harrow \& Heston.

. In this volume. "Situational Crime Prevention."

Clarke, R. V., and D. B. Cornish. 1985. Crime Control in Britain: A Review of Policy Research. Albany: State University of New York Press.

Clarke, R. V., and T. Hope, eds. 1984. Coping with Burglary. Boston: KluwerNijhoff.

Clarke, R. V., and J. M. Hough, eds. 1980. The Effectiveness of Policing. Farnborough: Gower.

Clarke, R. V., and P. Mayhew, eds. 1980. Designing out Crime. London: H.M. Stationery Office.

Cloward, R. A., and L. E. Ohlin. 1960. Delinquency and Opportunity. Glencoe, Ill.: Free Press.

Cohen, L. E., and M. Felson. 1979. "Social Change and Crime Rate Trends: A Routine Activities Approach." American Sociological Review 44:588608.

Cohen, S. 1985. Visions of Social Control. Cambridge: Polity Press.

Coleman, A. 1985. Utopia on Trial. London: Hilary Shipman.

Conklin, J. E. 1975. The Impact of Crime. New York: Basic.

Currie, E. 1988. "Two Visions of Community Crime Prevention." In Communities and Crime Reduction, edited by T. Hope and M. Shaw. London: H.M. Stationery Office.

Curtis, L. A. 1988. "The March of Folly: Crime and the Underclass." In Communities and Crime Reduction, edited by T. Hope and M. Shaw. London: H.M. Stationery Office.

Dahrendorf, R. 1985. Law and Order: The Hamlyn Lectures. London: Stevens.

Davis, Mike. 1990. City of Quartz. London: Verso.

Department of the Environment. 1981. An Investigation of Difficult to Let Housing. HDD Occasional Papers, March 1980. Vol. 1, General Findings, April 
1980. Vol. 2, Case Studies of Post War Estates, May 1980. Vol. 3, Case Studies of Pre War Estates, May 1980. London: H.M. Stationery Office.

DuBow, F., and D. Emmons. 1981. "The Community Hypothesis." In Reactions to Crime, edited by D. A. Lewis. Beverly Hills, Calif.: Sage.

DuBow, F., and A. Podolefsky. 1982. "Citizen Participation in Community Crime Prevention." Human Organization 41:307-14.

Duffee, D. 1980. Explaining Criminal Justice: Community Theory and Criminal Justice Reform. Cambridge, Mass.: Oelgeschlager, Gunn, \& Hain.

Eisenhower Foundation. 1990. Youtb Investment and Community Reconstruction: Street Lessons and Drugs and Crime for the Nineties. Washington, D.C.: Eisenhower Foundation.

Ekblom, Paul, and Ken Pease. In this volume. "Evaluating Crime Prevention."

Fagan, J. 1987. "Neighborhood Education, Mobilization, and Organization for Juvenile Crime Prevention." Annals of the American Acadamy of Political and Social Science 494:54-70.

Farrell, G. In this volume. "Preventing Repeat Victimization."

Farrell, G., and K. Pease. 1993. Once Bitten, Twice Bitten: Repeat Victimisation and Its Implications for Crime Prevention. Crime Prevention Unit Series Paper no. 46. London: Home Office Police Department.

Feins, J. D. 1983. Partnerships for Neigbborbood Crime Prevention. Washington, D.C.: National Institute of Justice.

Felson, M. 1987. "Routine Activities and Crime Prevention in the Developing Metropolis." Criminology 25:911-31.

- 1994. Crime and Everyday Life. Thousand Oaks, Calif.: Pine Forge.

Field, S., and T. Hope. 1990. "Economics, the Consumer and Underprovision in Crime Prevention." In Policing Organised Crime and Crime Prevention: British Criminology Conference 1989, vol. 4, edited by R. Morgan. Bristol: Bristol Centre for Criminal Justice.

Finestone, H. 1976. Victims of Change. Westport, Conn.: Greenwood.

Forrest, R., and A. Murie. 1988. Selling the Welfare State: The Privatisation of Public Housing. London: Routledge.

Forrester, D., M. Chatterton, and K. Pease. 1988. The Kirkbolt Burglary Prevention Project: Rocbdale. Crime Prevention Unit Paper no. 13. London: Home Office.

Forrester, D., S. Frenz, M. O'Connell, and K. Pease. 1990. The Kirkbolt Burglary Prevention Project: Pbase 2. Crime Prevention Unit Paper no. 23. London: Home Office.

Foster, J., and T. Hope. 1993. Housing, Community and Crime: The Impact of the Priority Estates Project. Home Office Research Study no. 131. London: H.M. Stationery Office.

Fowler, F. J., M. E. McCalla, and T. W. Mangione. 1979. Reducing Residential Crime and Fear: The Hartford Neigbborbood Crime Prevention Program. Washington, D.C.: National Institute of Justice.

Fowler, F. J., and T. W. Mangione. 1982. Neigbborbood Crime, Fear and Social Control: A Second Look at the Hartford Program. Washington, D.C.: National Institute of Justice.

- 1986. "A Three-pronged Effort to Reduce Crime and Fear of Crime: 
The Hartford Experiment." In Community Crime Prevention: Does It Work? edited by D. P. Rosenbaum. Beverly Hills, Calif.: Sage.

Freudenberg, W. 1986. "The Density of Acquaintanceship: An Overlooked Variable in Community Research." American Journal of Sociology 92:27-63.

Fried, A. 1969. "The Attack on Mobilization." In Community Development in the Mobilization for Youth Experience, edited by H. H. Weissman. New York: Association Press.

Furstenberg, F. 1993. "How Families Manage Risk and Opportunity in Dangerous Neighborhoods." In Sociology and the Public Agenda, edited by W. J. Wilson. Newbury Park, Calif.: Sage.

Genn, H. 1988. "Multiple Victimisation." In Victims of Crime: A New Deal? edited by M. Maguire and J. Pointing. Milton Keynes: Open University Press.

Giddens, A. 1990. The Consequences of Modernity. Cambridge: Polity.

Glennerster, H., and T. Turner. 1993. Estate Based Housing Management: An Evaluation. Department of the Environment. London: H.M. Stationery Office.

Granovetter, M. S. 1973. "The Strength of Weak Ties." American Journal of Sociology 76:1360-80.

Greenberg, S. W., W. M. Rohe, and J. R. Williams. 1985. Informal Citizen Action and Crime Prevention at the Neigbborbood Level. Washington, D.C.: National Institute of Justice.

Halsey, A. H. 1978. "Government against Poverty in School and Community." In Social Policy Research, edited by M. Bulmer. London: Macmillan.

Harvey, D. 1989. The Condition of Postmodernity. Cambridge, Mass.: Blackwell. Heal, K., and G. Laycock. 1986. Situational Crime Prevention: From Theory into Practice. London: H.M. Stationery Office.

Hedges, A., A. Blaber, and B. Mostyn. 1980. Community Planning Project: Cunningham Road Improvement Scheme Final Report. London: Social and Community Planning Research.

Helfgot, J. H. 1981. Professional Reforming: Mobilization for Youth and the Failure of Social Science. Lexington, Mass.: D. C. Heath.

Hesseling, R. B. P. 1992. "Social Caretakers and Preventing Crime on Public Housing Estates." In Dutch Penal Law and Policy 06, 05-1992. The Hague: Ministry of Justice, Research and Documentation Center.

Hirsch, A. R. 1983. Making the Second Gbetto. Cambridge: Cambridge University Press.

Hope, T. 1984. "Building Design and Burglary." In Coping with Burglary: Research Perspectives in Policy, edited by R. Clarke and T. Hope. Boston: Kluwer-Nijhoff.

- 1986a. "Crime, Community and Environment." Journal of Environmental Psychology 6:65-78.

—. 1986b. "Council Tenants and Crime." Researcb Bulletin 21:46-51. London: Home Office Research and Planning Unit.

1988a. "Support for Neighbourhood Watch: A British Crime Survey Analysis." In Communities and Crime Reduction, edited by T. Hope and M. Shaw. London: H.M. Stationery Office. 
1988b. "Everybody Needs Good Neighbours: Support for Anti-Crime Community Organizations." Paper presented at the annual meeting of the American Society of Criminology, Chicago, November.

—_. 1989. "Burglary and Vandalism in Schools: A Study of Theory and Practice in the Prevention of Crime." Ph.D. thesis, University of London, Faculty of Economics.

1994. "Problem-oriented Policing and Drug Market Locations: Three Case Studies." In Crime Prevention Studies, vol. 2, edited by R. W. Clarke. Monsey, N.Y.: Criminal Justice Press.

Hope, T., and J. Foster. 1992. "Conflicting Forces: Changing the Dynamics of Crime and Community on a 'Problem' estate." British Journal of Criminology 32:488-504.

Hope, T.; and M. Hough. 1988. "Area, Crime and Incivility: A Profile from the British Crime Survey." In Communities and Crime Reduction, edited by T. Hope and M. Shaw. London: H.M. Stationery Office.

Hope, T., and M. Shaw. 1988. "Community Approaches to Reducing Crime." In Communities and Crime Reduction, edited by T. Hope and M. Shaw. London: H.M. Stationery Office.

Horowitz, R. 1983. Honor and the American Dream. New Brunswick, N.J.: Rutgers University Press.

Hough, M., and P. Mayhew. 1985. Taking Account of Crime. Home Office Research Study no. 85. London: H.M. Stationery Office.

Husain, S. 1988. Neigbbourbood Watch in England and Wales: A Locational Analysis. Crime Prevention Unit Paper no. 12. London: Home Office.

Jacobs, B. D. 1992. Fractured Cities: Capitalism, Community and Empowerment in Britain and America. London: Routledge.

Jacobs, J. 1962. The Death and Life of Great American Cities. Harmondsworth: Penguin.

Kahn, A. J. 1968. "From Delinquency Treatment to Community Development." In The Uses of Sociology, edited by P. F. Lazarsfeld, W. H. Sewell, and H. L. Wilensky. London: Weidenfeld \& Nicolson.

Kasarda, J. D., and M. Janowitz. 1974. "Community Attachment in Mass Society." American Sociological Reveiw 39:328-39.

Kobrin, S. 1962. "The Chicago Area Project." In The Sociology of Punisbment and Correction, edited by N. Johnston, L. Savitz, and M. Wolfgang. New York: Wiley.

Kornhauser, R. R. 1978. Social Sources of Delinquency. Chicago: University of Chicago Press.

Kotlowitz, A. 1991. There Are No Cbildren Here. New York: Anchor.

Krohn, Marvin D. 1986. "The Web of Conformity: A Network Approach to the Explanation of Delinquent Behavior." Social Problems 33:S81-S93.

Land, K. C., P. L. McCall, and L. E. Cohen. 1990. "Structural Covariates of Homicide Rates." American Journal of Sociology 95:922-63.

Lash, S., and J. Urry. 1994. Economies of Signs and Space. London: Sage.

Lavrakas, P. J. 1981. "On Households." In Reactions to Crime, edited by D. A. Lewis. Beverly Hills, Calif.: Sage.

- 1985. "Citizen Self-Help and Neighborhood Crime Prevention Pol- 
icy." In American Violence and Public Policy, edited by L. A. Curtis. New Haven, Conn.: Yale University Press.

Lavrakas, P. J., and S. F. Bennett. 1989. A Process and Impact Evaluation of the 1983-86 Neigbborbood Anti-Crime Self-Help Program: Summary Report. Evanston, Ill.: Northwestern University, Center for Urban Affairs and Policy Research.

Lavrakas, P. J., and W. J. Herz. 1982. "Citizen Participation in Neighborhood Crime Prevention." Criminology 20:479-98.

Lemann, N. 1991. The Promised Land: The Great Black Migration and How It Changed America. New York: Knopf.

Lewis, D. A. 1979. "Design Problems in Public Policy Development: The Case of the Community Anti-crime Program." Criminology 17:172-83.

Lewis, D. A., J. A. Grant, and D. P. Rosenbaum. 1988. The Social Construction of Reform. New Brunswick, N.J.: Transaction Books.

Lewis, D. A., and G. Salem. 1981. "Community Crime Prevention: An Analysis of a Developing Strategy." Crime and Delinquency 27:405-21.

Lindblom, C. E., and D. K. Cohen. 1979. Usable Knowledge. New Haven, Conn.: Yale University Press.

Lindsay, B., and D. McGillis. 1986. "Citywide Community Crime Prevention: An Assessment of the Seattle Program." In Community Crime Prevention: Does It Work? edited by D. P. Rosenbaum. Beverly Hills, Calif.: Sage.

Logan, J. H., and H. Molotch. 1987. Urban Fortunes: The Political Economy of Place. Berkeley, Calif.: University of California Press.

Lurigio, A. J., and D. P. Rosenbaum. 1986. "Evaluation Research in Community Crime Prevention: A Critical Look at the Field." In Community Crime Prevention: Does It Work? edited by D. P. Rosenbaum. Beverly Hills, Calif.: Sage.

McConville, M., and D. Shepherd. 1992. Watching Police, Watching Communities. London: Routledge.

McGahey, R. M. 1986. "Economic Conditions, Neighborhood Organization, and Urban Crime." In Communities and Crime, edited by A. J. Reiss, Jr., and M. Tonry. Vol. 8 of Crime and Justice: A Review of Research, edited by M. Tonry and N. Morris. Chicago: University of Chicago Press.

McPherson, M., and G. Silloway. 1981. "Planning to Prevent Crime." In Reactions to Crime, edited by D. A. Lewis. Beverly Hills, Calif.: Sage.

Marris, P., and M. Rein. 1972. Dilemmas of Social Reform. Harmondsworth: Penguin.

Maxfield, Michael G. 1987. "Household Composition, Routine Activity and Victimization: A Comparative Analysis." Journal of Quantitative Criminology 3: 301-20.

Mayhew, P. 1977. "Defensible Space: The Current Status of a Crime Prevention Theory." Howard Journal 18:150-59.

Mayhew, P., R. V. G. Clarke, J. N. Burrows, J. M. Hough, and S. W. C. Winchester. 1979. Crime in Public View. Home Office Research Study no. 49. London: H.M. Stationery Office.

Mayhew, P., D. Elliott, and L. Dowds. 1989. The 1988 British Crime Survey. Home Office Research Study no. 111. London: H.M. Stationery Office. 
Merry, S. E. 1981. Urban Danger: Life in a Neigbborbood of Strangers. Philadelphia: Temple University Press.

Messner, S. F., and R. M. Golden. 1992. "Racial Inequality and Racially Disaggregated Homicide Rates: An Assessment of Alternative Theoretical Explanations." Criminology 30:421-45.

Messner, S. F., and R. J. Sampson. 1991. "The Sex Ratio, Family Disruption, and Rates of Violent Crime: The Paradox of Demographic Structure." Social Forces 69:693-713.

Moore, M. H. 1992. "Problem-solving and Community Policing." In Modern Policing, edited by M. Tonry and N. Morris. Vol. 15 of Crime and Justice: $A$ Review of Research, edited by M. Tonry. Chicago: University of Chicago Press.

Moynihan, D. P. 1969. Maximum Feasible Misunderstanding. New York: Free Press.

National Association for the Care and Resettlement of Offenders. 1989. Crime Prevention and Community Safety: A Practical Guide for Local Autborities. London: National Association for the Care and Resettlement of Offenders.

Newman, O. 1973. Defensible Space. London: Architectural Press.

1980. Community of Interest. Garden City, N.Y.: Anchor/Doubleday.

Newman, O., and K. A. Franck. 1980. Factors Influencing Crime and Instability in Urban Housing Developments. Washington, D.C.: National Institute of Justice.

Olsen, M. 1965. The Logic of Collective Action. New York: Schocken.

Osborn, D. R., A. Trickett, and R. Elder. 1992. "Area Characteristics and Regional Variates as Determinants of Area Property Crime Levels." Journal of Quantitative Criminology 8:265-85.

Painter, K. 1992. "The Impact of Street Lighting on Crime and Fear of Crime: Summary of Methods and Key Findings From an Ongoing Research Programme in the United Kingdom." Paper presented at the annual meeting of the American Society of Criminology, New Orleans, November.

Park, R. E., E. W. Burgess, and R. D. McKenzie. 1925. The City. Chicago: University of Chicago Press.

Pease, K. 1992. "Preventing Burglary on a British Housing Estate." In Situational Crime Prevention: Successful Case Studies, edited by R. V: Clarke. New York: Harrow \& Heston.

1993. "Individual and Community Influences on Victimisation and Their Implications for Prevention." In Integrating Individual and Ecological Aspects of Crime, edited by D. P. Farrington, R. J. Sampson, and P.-O. H. Wikström. Stockholm: National Council for Crime Prevention.

Piven, F. F. 1969. "Politics and Planning: Mobilization as a Model." In Justice and Law in the Mobilization for Youth Experience, edited by H. H. Weissmann. New York: Association Press.

Piven, F. F., and R. A. Cloward. 1971. Regulating the Poor. New York: Pantheon.

Podolefsky, A. 1983. Case Studies in Community Crime Prevention. Springfield, Ill.: Charles C. Thomas.

Podolefsky, A., and F. DuBow. 1981. Strategies for Community Crime Prevention. Springfield, Ill.: Charles C. Thomas. 
Power, A. 1984. Local Housing Management. London: Department of the Environment.

- 1987a. Property before People. London: Allen \& Unwin.

- 1987b. The PEP Guide to Local Management. Vol. 1, The PEP Model. Vol. 2, The PEP Experience. Vol. 3, Guidelines for Setting UP New Projects. London: Department of the Environment.

- 1988. "Housing, Community and Crime." In Crime and the City: Essays in Memory of Jobn Barron Mays, edited by D. Downes. Basingstoke: Macmillan.

Poyner, B. 1983. Design against Crime. London: Butterworths.

President's Commission on Law Enforcement and Administration of Justice. 1967. The Challenge of Crime in a Free Society. Washington, D.C.: U.S. Government Printing Office.

Ramsay, M. 1991. The Effect of Better Street Lighting on Crime and Fear: A Review. Crime Prevention Unit Paper no. 29: London: Home Office.

Rein, M. 1976. Social Science and Social Policy. Harmondsworth: Penguin.

- 1983. From Policy to Practice. London: Macmillan.

Reynolds, F. 1986. The Problem Estate. Aldershot: Gower.

Riley, D. 1992. Personal communication with author. London: Department of the Environment.

Rock, P. 1988. "Crime Reduction Initiatives on Problem Estates." In Communities and Crime Reduction, edited by T. Hope and M. Shaw. London: H.M. Stationery Office.

Roncek, Dennis W. 1981. "Dangerous Places: Crime and Residential Environment." Social Forces 60:74-96.

Rosenbaum, D. P., ed. 1986. Community Crime Prevention: Does It Work? Beverly Hills, Calif.: Sage.

— 1987. "The Theory and Research behind Neighborhood Watch: Is It a Sound Fear and Crime Reduction Strategy?" Crime and Delinquency 33:103-43.

—. 1988a. "Community Crime Prevention: A Review and Synthesis of the Literature." Justice Quarterly 5:323-95.

- 1988b. "A Critical Eye on Neighbourhood Watch: Does It Reduce Crime and Fear?" In Communities and Crime Reduction, edited by T. Hope and M. Shaw. London: H.M. Stationery Office.

Rosenbaum, D. P., D. A. Lewis, and J. A. Grant. 1986. "Neighborhoodbased Crime Prevention: Assessing the Efficacy of Community Organizing in Chicago." In Community Crime Prevention: Does It Work? edited by D. P. Rosenbaum. Beverly Hills, Calif.: Sage.

Rubenstein, H., C. Murray, T. Motoyama, W. V. Rouse, and R. M. Titus. 1980. The Link between Crime and the Built Environment. Vol. 1. The Current State of Knowledge. Washington, D.C.: National Institute of Justice.

Safe Neighbourhoods Unit. 1993a. Crime Prevention on Council Estates. Department of the Environment. London: H.M. Stationery Office.

- 1993b. Housing and Safe Communities: An Evaluation of Recent Initiatives. London: Safe Neighbourhoods Unit.

Sampson, R. J. 1985. "Neighborhood and Crime: The Structural Determi- 
nants of Personal Victimisation." Journal of Research in Crime and Delinquency 22:7-40.

- 1987a. "Communities and Crime." In Positive Criminology, edited by M. R. Gottfredson and T. Hirschi. Newbury Park, Calif.:Sage.

- 1987b. "Urban Black Violence: The Effect of Male Joblessness and Family Disruption." American Journal of Sociology 93:348-82.

- 1992. "The Community Context of Violent Crime." In Sociology and the Public Agenda, edited by W. J. Wilson. Newbury Park, Calif.: Sage.

Sampson, R. J., and W. B. Groves. 1989. "Community Structure and Crime: Testing Social Disorganisation Theory." American Journal of Sociology 94: 774-802.

Schlossman, S., G. Zellman, and R. Shavelson. 1984. Delinquency Prevention in South Cbicago: A Fifty-Year Assessment of the Cbicago Area Project. Santa Monica, Calif.: RAND.

Schuerman, L., and S. Kobrin. 1986. "Community Careers in Crime." In Communities and Crime, edited by A. J. Reiss, Jr., and M. Tonry. Vol. 8 of Crime and Justice: A Review of Research, edited by M. Tonry and N. Morris. Chicago: University of Chicago Press.

Shapland, J., and J. Vagg. 1988. Policing by the Public. London: Routledge.

Shaw, C. R., and H. D. McKay. 1969. Juvenile Delinquency and Urban Areas. Chicago: University of Chicago Press.

Short, J. F. 1975. "The Natural History of an Applied Theory: Differential Opportunity and 'Mobilization for Youth."' In Social Policy and Sociology, edited by N. J. Demerath, O. Larson, and K. F. Schuessler. New York: Academic Press.

Skogan, W. G. 1986. "Fear of Crime and Neighborhood Change." In Communities and Crime, edited by A. J. Reiss, Jr., and M. Tonry. Vol. 8 of Crime and Justice: A Review of Research, edited by M. Tonry and N. Morris. Chicago: University of Chicago Press.

- 1988. "Community Organizations and Crime." In Crime and Justice: A Review of Research, vol. 10, edited by M. Tonry and N. Morris. Chicago: University of Chicago Press.

. 1990. Disorder and Decline: Crime and the Spiral of Decay in American Neigbbourboods. New York: Free Press.

Skogan, W. G., and M. G. Maxfield. 1981. Coping with Crime. Beverly Hills, Calif.: Sage.

Smith, Douglas A., and R. Jarjoura. 1989. "Household Characteristics, Neighborhood Composition and Victimization Risk." Social Forces 68:62140.

Sullivan, M. L. 1989. Getting Paid: Youth Crime and Work in the Inner City. Ithaca, N.Y.: Cornell University Press.

Suttles, Gerald D. 1968. The Social Order of the Slum. Chicago: University of Chicago Press.

. 1972. The Social Construction of Communities. Chicago: University of Chicago Press.

Taub, R. P., D. G. Taylor, and J. D. Dunham. 1984. Patbs of Neigbborbood Change. Chicago: University of Chicago Press. 
Taylor, R. B., and J. Covington. 1988. "Neighborhood Changes in Ecology and Violence." Criminology 26:553-89.

Taylor, R. B., and S. Gottfredson. 1986. "Environmental Design, Crime, and Prevention: An Examination of Community Dynamics." In Communities and Crime, edited by A. J. Reiss, Jr., and M. Tonry. Vol. 8 of Crime and Justice: A Review of Research, edited by M. Tonry and N. Morris. Chicago: University of Chicago Press.

Taylor, R. B., S. D. Gottfredson, and S. Brower. 1980. "The Defensibility of Defensible Space: A Critical Review and a Synthetic Framework for Future Research." In Understanding Crime, edited by $\mathrm{T}$. Hirschi and $\mathrm{M}$. Gottfredson. Beverly Hills, Calif.: Sage.

Tien, J, V. F. 'O'Donnell, A. Barnett, and P. B. Mirchandani. 1979. Street Lighting Projects: National Evaluation Program, Phase 1 Report. Washington, D.C.: National Institute of Law Enforcement and Criminal Justice.

Tilley, N. 1993. After Kirkbolt: Theory, Metbod, and Results of Replication Evaluations. Crime Prevention Unit Series Paper no. 47. London: Home Office Police Department.

Titus; R. M. 1984. "Residential Burglary and the Community Response." In Coping with Burglary: Research Perspectives in Policy, edited by R. Clarke and T. Hope. Boston: Kluwer-Nijhoff.

Toby, J. 1957. "Social Disorganization and Stake in Conformity: Complementary Factors in the Predatory Behavior of Hoodlums." Journal of Criminal Law, Criminology and Police Science 48:12-17.

Trickett, A., D. Ellingworth, and K. Pease. 1992. "Changes in Area Inequality in Crime Victimisation, 1982-88: Findings from the British Crime Surveys." Unpublished manuscript. Manchester: University of Manchester, Department of Social Policy and Social Work.

Trickett, Alan, Denise R. Osborn, Julie Seymour, and Ken Pease. 1992. "What Is Different about High Crime Areas?" British Journal of Criminology 32:81-89.

Wallis, A., and D. Ford, eds. 1980. Crime Prevention through Environmental Design: The Commercial Demonstration in Portland, Oregon. Washington, D.C.: National Institute of Justice.

Ward, C., ed. 1973. Vandalism. London: Architectural Press.

Webster, B., and E. F. Connors. 1992. The Police, Drugs, and Public Housing. National Institute of Justice Research in Brief. Washington, D.C.: U.S Department of Justice.

Whyte, W. F. 1955. Street Corner Society. 2d ed. Chicago: University of Chicago Press.

Wildavsky, A. 1980. The Art and Craft of Policy Analysis. London: Macmillan.

Willmott, P., and A. Murie. 1988. Polarisation and Social Housing. London: Policy Studies Institute.

Wilson, J. Q. 1975. Thinking about Crime. New York: Basic.

- 1978. "Social Science and Public Policy: A Personal Note." In Knowledge and Public Policy: The Uncertain Connection, edited by L. E. Lynn. Washington, D.C.: National Academy of Sciences.

. 1985. Thinking about Crime. Rev. ed. New York: Vintage. 
Wilson, J. Q., and R. J. Herrnstein. 1985. Crime and Human Nature. New York: Simon \& Schuster.

Wilson, J. Q., and G. Kelling. 1982. "Broken Windows: The Police and Neighborhood Safety." Atlantic Monthly 249(3):29-38.

Wilson, W. J. 1987. The Truly Disadvantaged. Chicago: University of Chicago Press.

- 1991a. "Studying Inner-City Social Dislocations: The Challenge of Public Agenda Research." American Sociological Review 56:1-14.

- 1991b. "Public Policy Research and the Truly Disadvantaged." In The Urban Underclass, edited by C. Jencks and P. E. Peterson. Washington, D.C.: Brookings Institution.

Wirth, L. 1938. "Urbanism as a Way of Life." American Journal of Sociology 44:1-24.

Wootton, B. 1959. Social Science and Social Patbology. London: Allen \& Unwin. 
HeinOnline -- 19 Crime \& Just. 901995 